medRxiv preprint doi: https://doi.org/10.1101/2020.10.26.20219642; this version posted April 21, 2021. The copyright holder for this preprint (which was not certified by peer review) is the author/funder, who has granted medRxiv a license to display the preprint in perpetuity.

It is made available under a CC-BY 4.0 International license .

\title{
A2B-COVID: A method for evaluating potential SARS-CoV-2 transmission events
}

\section{Authors}

Christopher J. R. Illingworth ${ }^{* 1,2}$, William L. Hamilton*3,4, Chris Jackson ${ }^{* 1}$, Ashley Popay ${ }^{5}$, Luke Meredith $^{6}$, Charlotte J. Houldcroft ${ }^{3}$, Myra Hosmillo ${ }^{6}$, Aminu Jahun ${ }^{6}$, Matthew Routledge ${ }^{4,9}$, Ben Warne $^{3,4}$, Laura Caller ${ }^{7}$, Sarah Caddy ${ }^{8}$, Anna Yakovleva ${ }^{6}$, Grant Hall ${ }^{6}$, Fahad A. Khokhar ${ }^{6}$, Theresa Feltwell ${ }^{3}$, Malte L. Pinckert ${ }^{6}$, Iliana Georgana ${ }^{6}$, Yasmin Chaudhry ${ }^{6}$, Martin Curran ${ }^{9}$, Surendra Parmar ${ }^{9}$, Dominic Sparkes ${ }^{4,9}$, Lucy Rivett ${ }^{4,9}$, Nick K. Jones ${ }^{4,9}$, Sushmita Sridhar ${ }^{3,8,10}$, Sally Forrest ${ }^{8}$, Tom Dymond ${ }^{4}$, Kayleigh Grainger ${ }^{4}$, Chris Workman ${ }^{4}$, Effrossyni GkraniaKlotsas $^{4,11,12}$, Nicholas M. Brown ${ }^{4,9}$, Michael P. Weekes ${ }^{3,8}$, Stephen Baker ${ }^{3,8}$, Sharon J. Peacock ${ }^{3}$,

${ }^{10}$, Theodore Gouliouris ${ }^{4,9}$, lan Goodfellow ${ }^{6}$, Daniela De Angelis ${ }^{1,13}$, M. Estée Török ${ }^{3,4}$

* Contributed equally

\section{Affiliations}

1. MRC Biostatistics Unit, University of Cambridge, East Forvie Building, Forvie Site, Robinson Way, Cambridge, CB2 0SR, United Kingdom

2. Institut für Biologische Physik, Universität zu Köln, Zülpicherstr. 77, 50937, Köln, Germany

3. University of Cambridge, Department of Medicine, Cambridge Biomedical Campus, Hills Road, Cambridge CB2 OQQ, United Kingdom

4. Cambridge University Hospitals NHS Foundation Trust, Cambridge Biomedical Campus, Hills Road, Cambridge CB2 OQQ, United Kingdom

5. Public Health England Field Epidemiology Unit, Cambridge Institute of Public Health, Forvie Site, Cambridge Biomedical Campus, Cambridge CB2 0SR, United Kingdom

\section{Correspondence}

6. University of Cambridge, Department of Pathology, Division of Virology, Cambridge Biomedical Campus, Hills Road, Cambridge CB2 0QQ, United Kingdom

7. Francis Crick Institute, 1 Midland Rd, Somers Town, London NW1 1AT, United Kingdom

8. Cambridge Institute for Therapeutic Immunology and Infectious Disease, Jeffrey Cheah Biomedical Centre, Puddicombe Way, Cambridge CB2 OAW, United Kingdom

9. Public Health England Clinical Microbiology and Public Health Laboratory, Cambridge Biomedical Campus, Hills Road, Cambridge CB2 0QQ, United Kingdom

10. Wellcome Sanger Institute, Wellcome Trust Genome Campus, Hinxton, CB10 1RQ

11. MRC Epidemiology Unit, University of Cambridge, Level 3 Institute of Metabolic Science, Cambridge CB2 0SL, United Kingdom

12. University of Cambridge, School of Clinical Medicine, Cambridge Biomedical Campus, Hills Road, Cambridge CB2 OQQ, United Kingdom

13. Public Health England, National Infection Service, 61 Colindale Avenue, London NW9 $5 E Q$, United Kingdom 
medRxiv preprint doi: https://doi.org/10.1101/2020.10.26.20219642; this version posted April 21, 2021. The copyright holder for this preprint (which was not certified by peer review) is the author/funder, who has granted medRxiv a license to display the preprint in perpetuity.

It is made available under a CC-BY 4.0 International license.

\section{Abstract}

Identifying linked cases of infection is a key part of the public health response to viral infectious disease. Viral genome sequence data is of great value in this task, but requires careful analysis, and may need to be complemented by additional types of data. The Covid-19 pandemic has highlighted the urgent need for analytical methods which bring together sources of data to inform

51 epidemiological investigations. We here describe A2B-COVID, an approach for the rapid

52 identification of linked cases of coronavirus infection. Our method combines knowledge about

53 infection dynamics, data describing the movements of individuals, and novel approaches to 54 genome sequence data to assess whether or not cases of infection are consistent or inconsistent 55 with linkage via transmission. We apply our method to analyse and compare data collected from 56 two wards at Cambridge University Hospitals, showing qualitatively different patterns of linkage 57 between cases on designated Covid-19 and non-Covid-19 wards. Our method is suitable for the 58 rapid analysis of data from clinical or other potential outbreak settings.

\section{Introduction}

Having emerged via zoonotic transfer in late 2019, the COVID-19 pandemic remains an ongoing

63 public health priority [1,2]. Understanding the nature of viral transmission is a key factor in all

64 strategies to prevent and control disease spread. The earliest stages of the outbreak were 65 characterised by small, localised clusters of infection $[3,4]$. Identifying chains of inked cases 66 remains crucial for containing disease spread [5,6], particularly in healthcare settings. Outbreaks

67 in these settings, however, provide a particular challenge to the identification of linked cases as 68 regular new introductions from the community have to be distinguished from potential cases of 69 nosocomial transmission [7-9]. 
medRxiv preprint doi: https://doi.org/10.1101/2020.10.26.20219642; this version posted April 21, 2021. The copyright holder for this preprint (which was not certified by peer review) is the author/funder, who has granted medRxiv a license to display the preprint in perpetuity.

It is made available under a CC-BY 4.0 International license .

71 Viral genome sequencing provides one strategy for identifying clusters of transmission. The rapid

72 evolution of viral populations leads to the accumulation over time of genetic differences which

73 distinguish linked from unlinked cases [10]. A broad range of phylogenetic approaches for

74 identifying linked infection clusters have previously been described [11-15]

76 With this background, a recent study of hospital-based COVID-19 infection used genome

77 sequencing to identify potential clusters of infection. In this study, sets of individuals with identical

78 viral genome sequences were often verified by a process of epidemiological follow-up to

79 correspond to likely cases of nosocomial transmission [5]. Data from genome sequencing allowed

80 feedback in real time to clinical, infection control and hospital management teams to inform their

81 response.

83 Whilst genome sequence data is of great value for studying viral transmission, it has some

84 drawbacks in the context of SARS-CoV-2. Given the recent emergence of SARS-CoV-2, and the

85 low diversity of global viral sequences, finding identical sequences in different individuals does

86 not necessarily imply a connection between those people. Furthermore, sequence data is not the

87 only type of information that may be available. For example, studies of known SARS-CoV-2

88 transmission events have quantified the distribution of times between the onset of symptoms and

89 the transmission of the virus, and of the subsequent time between infection and the onset of

90 symptoms [16-19]. In addition the contribution of asymptomatic individuals to transmission is

91 difficult to ascertain as they may not be sampled [20,21]. Such information has implications for

92 the analysis of potential transmission events. Information about the location of individuals might

93 also contribute to the identification or ruling out of connections; people who never physically

94 interact cannot directly transmit the virus from one to another. Potential, therefore, exists for novel 95 approaches in the identification of transmission clusters. 
medRxiv preprint doi: https://doi.org/10.1101/2020.10.26.20219642; this version posted April 21, 2021. The copyright holder for this preprint (which was not certified by peer review) is the author/funder, who has granted medRxiv a license to display the preprint in perpetuity.

It is made available under a CC-BY 4.0 International license .

97 New methodologies have the potential to gain insights into viral sequence data. For example,

98 noise in the process of viral sequencing can affect phylogenetic analyses which rely on finding

99 identical sequences. Multiple studies have considered the problem of noise in genome sequence

100 data, particularly with regard to identifying variant frequencies [22-25]. The potential for error in

101 variant frequencies means that a viral consensus sequence is also stochastic, since it is

102 generated from a potentially diverse viral population. Further, evolution would be expected to

103 change viral sequences over time. Metrics which account for measurement error and viral

104 evolution may be advantageous for identifying linked cases of infection.

105

106 A variety of studies have used short-read viral sequencing to evaluate the nature and likely 107 direction of viral transmission. The ability of such data to capture the diversity of within-host viral 108 populations has proved very valuable in the assessment of transmission events [26-29]. 109 However, the low cost of data collection via nanopore-based methods has often outweighed the 110 additional precision provided by Illumina technology [30,31]. Analyses which can utilise the 111 consensus sequences provided by such methods have broader application, increasing their 112 value.

114 Here, we describe a tool which implements a combined statistical and evolutionary framework to 115 analyse genome sequence data with location data and knowledge of SARS-CoV-2 infection 116 dynamics to rapidly identify clusters of infection. Our approach provides a rapid data analysis, 117 outputting information in an easily interpretable format. We demonstrate its use with augmented 118 sequence data from outbreaks on hospital wards, illustrating the value of different kinds of data 119 in this context. While designed with clinical application in mind, the generality of the properties of 120 viral transmission make our method applicable to any setting in which appropriate data has been 
medRxiv preprint doi: https://doi.org/10.1101/2020.10.26.20219642; this version posted April 21, 2021. The copyright holder for this preprint (which was not certified by peer review) is the author/funder, who has granted medRxiv a license to display the preprint in perpetuity.

It is made available under a CC-BY 4.0 International license .

121 collected from more than one individual. We hope that our approach will be of value in ongoing

122 public health efforts to combat the COVID-19 pandemic.

\section{Results}

Our method exploits data from genome sequencing alongside other information about individuals

127 and COVID-19 infection. Given short periods of time between samples, the extent of measurement error in a viral sample may exceed the extent of evolutionary change in a population [32]. As a preliminary step therefore, we evaluated the extent of measurement error in our sequencing pipeline.

We examined cases among data collected from patients at the Cambridge University Hospitals National Health Service Foundation Trust (CUH) for which more than one viral sample was sequenced. A total of 136 such patients were identified, with between 2 and 9 (median 2) samples collected from each individual and 336 samples in total. Intervals between pairs of samples varied

136 from 0 to 39 days. Each sample gave rise to a consensus sequence. We filtered the data to 137 remove sequences with less than $90 \%$ coverage of the genome. Combining these data through 138 regression, we inferred a mean error rate of approximately 0.207 nucleotide errors per sequence 139 (S1 Figure). While small, this rate is significant. In our model, the expected time between symptoms being reported from individuals in a transmission pair is 5.7 days; the expected amount of sequence evolution within this time is not greater than the expected difference between two sequences resulting from noise (S2 Figure).

144 For each pair of individuals in a dataset we compared symptom onset, location, and genome sequence data with an underlying model of transmission, identifying whether or not the data were 
medRxiv preprint doi: https://doi.org/10.1101/2020.10.26.20219642; this version posted April 21, 2021. The copyright holder for this preprint (which was not certified by peer review) is the author/funder, who has granted medRxiv a license to display the preprint in perpetuity.

It is made available under a CC-BY 4.0 International license .

147 individuals. Our model produces a simple output, stating that the data are either 'consistent' with

148 the hypothesis of transmission (nominal p-value $>0.05$ ), that transmission is 'unlikely' to have 149 occurred ( $p$-value $<0.01$ ) or that the case is 'borderline' ( $p$-value between 0.05 and 0.01 ).

We applied our model to data from two wards within $\mathrm{CUH}$, which we term $\mathrm{X}$ and $\mathrm{Y}$. Ward $\mathrm{X}$ was

a 'green' ward, used for patients considered to be free from COVID-19 infection. By contrast, ward $Y$ was a 'red' ward within the hospital, designated for the treatment of patients with COVID-

15419 infection, on which multiple cases of infection in healthcare workers (HCWs) were identified.

155 Information collected for these individuals included genome sequence data from viral swabs, dates of symptom onset and dates on which individuals were present on the wards in question.

Our method combines multiple types of data, using the information available to identify potentially of symptom onset and the viral sequence data. unlikely. This is in part explained by 7069 reporting symptoms four days before 7074 ; the order

169 of the output from our code can be used to identify potential clusters of linked transmission events.

170 For example, data from ward $X$ suggest that the ten infections for which data were available were

171 potentially mutually connected by transmission, though some underlying structure can be seen.

172 The bottom three individuals coded 7108,7128 , and 7074 , could each have infected each other, 
medRxiv preprint doi: https://doi.org/10.1101/2020.10.26.20219642; this version posted April 21, 2021. The copyright holder for this preprint (which was not certified by peer review) is the author/funder, who has granted medRxiv a license to display the preprint in perpetuity.

It is made available under a CC-BY 4.0 International license.

173 but have only borderline chances of having infected anyone else on the ward. These individuals

174 could have been infected by either 7069 or 7112 infecting 7074 , leading to further transmission

175 events. The remainder of the individuals on the ward show multiple plausible transmission events,

176 though we note that 7129 has only a borderline probability of having infected any other person.

177 Examination of location data collected for the ward provides some insight into these findings

178 (Figure 2B). Individuals 7108 and 7128 were never present on ward $\mathrm{X}$, but were mutually in

179 contact with 7074 throughout the duration of the outbreak via known household contacts. The

180 health care worker 7129 was present on ward $\mathrm{X}$ at the same time as many of the other individuals,

181 but became symptomatic at a later point; the later onset of symptoms suggests that 7129 was

182 infected by another individual in the outbreak without passing the virus on within the ward. The

overall picture we discover is what may be a single outbreak of linked cases on ward X, potentially

started by a patient, but largely involving HCWs both on and off the ward.

Analysis of data from ward $\mathrm{Y}$ revealed a less complex chain of events (Figure 2C). Precisely two connections between individuals can again be understood from the location data that do exist (Figure 2D). We note that in ward $\mathrm{Y}$, cases were spread over a longer period of time than in ward reported on the ward not being linked to these individuals. Our results reflect the 'green' and 'red'

194 natures of the two wards. Where ward X was designated for patients who were in theory free 195 from COVID-19 infection, a coherent cluster of infection, potentially indicating a single introduction 196 of the virus into the ward, was responsible for all of the observed cases. By contrast ward Y, 197 being designated for COVID-19 cases, had multiple introductions of the virus onto the ward, 198 perhaps two of those cases leading to ongoing nosocomial transmission. 
medRxiv preprint doi: https://doi.org/10.1101/2020.10.26.20219642; this version posted April 21, 2021. The copyright holder for this preprint (which was not certified by peer review) is the author/funder, who has granted medRxiv a license to display the preprint in perpetuity.

It is made available under a CC-BY 4.0 International license .

200 Sensitivity analyses suggested that the measurement error has some effect on the outputs of our

201 model. Calculations performed with increased and decreased error parameters led to changes

202 in which events were identified as 'Consistent', 'Borderline' or 'Unlikely' (S3 Figure). Reducing

203 the input error parameter to zero has the potential to induce more significant changes in our model

204 output, as discussed further in the Methods section.

206 In order to assess the value of location data we repeated our estimation in their absence, using 207 only viral genome sequence data and the dates on which individuals first reported symptoms.

208 Location data generally reduces the inferred potential for viral transmission; under the logic of our 209 method, individuals who are not in the same place at the same time cannot infect one another.

210 The value of location data in increasing the precision with which networks of links between cases

211 of infection is shown by the results from ward $X$ (Figure $3 A$ ). While the overall pattern of data

212 shows multiple potential connections between individuals, the independence of the transmissions

213 between 7108,7128 , and 7074 from the remainder of the network was lost in the absence of

214 spatial data. Spatial data in our model was defined in terms of presence or absence on a ward,

215 more refined information not being available. An analysis of data from ward $Y$ showed an intriguing

216 result, with previously unseen potential links between individual 2019 and the first cluster, and

217 between 3327 and the second cluster (Figure 3B). These HCW displayed symptoms earlier than

218 the people in their respective clusters, consistent with being the original cases in each case.

219 Further, phylogenetic reconstruction showed that the sequences from these individuals were

220 consistent with their being linked (Figure 3C; similar data for ward X is shown in S4 Figure).

221 However, the location data do not show them as working shifts on ward $\mathrm{Y}$ at the same time as

222 any of the other linked individuals were present. We suggest that unrecorded contacts may exist

223 in this case. 
medRxiv preprint doi: https://doi.org/10.1101/2020.10.26.20219642; this version posted April 21, 2021. The copyright holder for this preprint (which was not certified by peer review) is the author/funder, who has granted medRxiv a license to display the preprint in perpetuity.

It is made available under a CC-BY 4.0 International license .

225 The potential for missing location data to prevent the identification of linked individuals shows that

226 measuring location can be difficult, more so for HCWs than patients. While patients are unlikely

227 to be highly mobile, HCWs move around the hospital outside of their shifts. Unless explicitly

228 recorded, off-ward contacts between HCWs are unlikely to be noted, leading to the potential non-

229 inference of genuine links. While missing location data cannot be unambiguously diagnosed as

230 the cause of our result, this case highlights the limitations intrinsic to our approach. Our software

231 may provide valuable insights, but does not replace the need for full epidemiological investigation.

\section{Discussion}

We have here set out a method for identifying potential cases of direct transmission between pairs of individuals, based upon the dynamics of SARS-CoV-2 infection, data describing times of colocation between individuals, and genome sequence data collected during infection. In a first application of our method, we analysed data from two hospital wards. In each, we identified cases where the data were consistent with viral transmission occurring between either patients or HCWs on the ward. Our method builds upon information that can be obtained from a phylogenetic

241 analysis, incorporating data from multiple sources to present an easily-interpretable map of

242 potential linked cases of infection. It is likely to be valuable in the initial assessment of potential 243 cases of nosocomial transmission, highlighting pairs or clusters of individuals for further 244 epidemiological assessment, and allowing for a more strategic deployment of resources for 245 outbreak investigation and targeted interventions.

247 Our method brings together a variety of data, combining an evolutionary model for the analysis of 248 sequence data with location information and details of the dynamics of viral infection. In contrast 249 to standard phylogenetic approaches to sequence data, our model explicitly accounts for noise in 
medRxiv preprint doi: https://doi.org/10.1101/2020.10.26.20219642; this version posted April 21, 2021. The copyright holder for this preprint (which was not certified by peer review) is the author/funder, who has granted medRxiv a license to display the preprint in perpetuity.

It is made available under a CC-BY 4.0 International license .

251 of error of a fraction of one nucleotide per genome. In rapidly evolving viruses for which

252 transmissions are separated by longer periods of time, the within-host evolution of viral

253 populations is likely to overwhelm the effect of noise in the sequencing process. However, for

254 cases of acute infection, separated by only a few days, the extent of noise may be close to the

255 expected evolutionary change in the population, making it an important factor to consider.

257 One limitation of our method is that it deals with consensus viral sequences rather than deep

258 sequence data. Where available, detailed measurements of within-host viral diversity may lead to

259 an improved picture of relationships between cases of viral infection. We note further that our

260 tool analyses data in a pairwise manner; while distinguishing plausible from implausible links

261 between cases of infection, it does not attempt to infer a complete reconstruction of a transmission

262 network. Unobserved cases of infection are not considered. Our model used parameters which

263 in some cases have been derived from early studies into SARS-CoV-2 spread. To account for

264 the event that further research leads to a better understanding of viral transmission we provide

265 options to perform calculations with user-specified parameters. We finally note that a statistical

266 inference from our model does not describe the probability of transmission having occurred

267 between two individuals. Instead it describes how consistent the data are with transmission. Our

268 model is intended as a first step towards further epidemiological investigation.

270 Our model has a range of features specifically tailoring it to the real-time analysis of data in a

271 hospital context during an outbreak of a rapidly spreading viral disease. Our method is designed

272 for simplicity both in being easy to use and in rapidly producing an interpretable output. To this

273 extent our method is limited in what we try to infer, highlighting only pairs of individuals where the

274 data are consistent with transmission. For example, in a case where an individual A infects B and

$275 \mathrm{C}$, it could be that our method highlights not only the real transmission events, but also reports

276 that the data from $B$ and $C$ is consistent with transmission occurring between them. This does 
medRxiv preprint doi: https://doi.org/10.1101/2020.10.26.20219642; this version posted April 21, 2021. The copyright holder for this preprint (which was not certified by peer review) is the author/funder, who has granted medRxiv a license to display the preprint in perpetuity.

It is made available under a CC-BY 4.0 International license .

277 not comprise an error in our method, but does require our method to be understood. We note

278 that, in a hospital environment, a positive output from our method could be followed up by

279 investigative efforts and epidemiological follow up; such efforts have the potential to collect data

280 beyond that considered by our method.

We believe that the key application of our method will be in investigating nosocomial transmission of SARS-CoV-2. Within a hospital, potential cases of transmission may be obscured by a large number of cases of community-acquired infection. In a busy clinical setting, our tool has the ability to rapidly separate potentially linked cases from those which are likely to be unlinked. In this way we allow investigative efforts and epidemiological followup to be focused more precisely, concentrating effort on cases where transmission is a real possibility.

\section{Methods}

\section{Model overview}

We here consider pairs of individuals, who for the purpose of notation, we describe as individuals

294 A and B. Given data on when the individuals became symptomatic for SARS-CoV-2 infection, 295 their locations, and their viral genome sequences, we generate a statistic to test whether the data 296 are consistent with viral transmission having occurred from A to B.

298 To outline this process, suppose that we have observed data y from this pair of individuals. The 299 null hypothesis of transmission is supported by the data if these data have high probability of 300 having arisen given transmission from A to B. More formally, the hypothesis is accepted at a 301 confidence level $\psi$ if the probability of observing y, or data that are "less extreme" (i.e. data that 
medRxiv preprint doi: https://doi.org/10.1101/2020.10.26.20219642; this version posted April 21, 2021. The copyright holder for this preprint (which was not certified by peer review) is the author/funder, who has granted medRxiv a license to display the preprint in perpetuity.

It is made available under a CC-BY 4.0 International license.

are even more consistent with transmission than y) is at least $\psi$ under the hypothesis of direct transmission from $A$ to $B$. We outline our method in detail below.

\section{Available data}

Notation

An overview of the notation used in the description of our model is shown in Figure 4. The dates of symptom onset and the dates when viral sequence data were collected are denoted $S_{A}$ and $S_{B}$ and $D_{A}$ and $D_{B}$, respectively. These dates are assumed to be known, or in the case of symptom dates can be estimated from times at which individuals tested positive. Further data described the locations of the individuals $A$ and $B$ on each day, with the binary indicator $C_{A}(L, T)$ denoting whether individual $A$ was present in location $L$ on day $T$. The information describing the location of individuals may be uncertain, so we represent it by $w_{A}(L, T)$, the probability that individual $A$ is present in location $L$ on day $T$. For example, if $A$ is known to be in location $L$ on day $T$ we have

$317 w_{A}(L, T)=1$, while if $A$ is known not to be in location $L$ on day $T$ we have $w_{A}(L, T)=0$. If the location of $A$ at this time is unknown, $w_{A}(L, T)$ is defined as described below. Analogously to this, the binary

319 indicator $\mathrm{C}_{A B}(\mathrm{~T})$ denotes whether or not $\mathrm{A}$ and $\mathrm{B}$ were in contact on day $\mathrm{T}$. Uncertainty in this 320 indicator is represented by the probability $\mathrm{w}_{\mathrm{AB}}(\mathrm{T})$ that $\mathrm{A}$ and $\mathrm{B}$ were present in the same location

321 on this day. In describing genomic data, $\mathrm{H}_{A}$ and $\mathrm{H}_{B}$ describe Hamming distances between the 322 viral sequences collected from $A$ and $B$ and their mutual consensus. The CT scores of the viral 323 samples are denoted $\mathrm{V}_{\mathrm{A}}$ and $\mathrm{V}_{\mathrm{B}}$. 
medRxiv preprint doi: https://doi.org/10.1101/2020.10.26.20219642; this version posted April 21, 2021. The copyright holder for this preprint (which was not certified by peer review) is the author/funder, who has granted medRxiv a license to display the preprint in perpetuity.

It is made available under a CC-BY 4.0 International license .

327 Due to extensive monitoring of individuals in hospital, we often had information on the dates of

328 symptom onset for individuals. When these were unknown we estimated them from positive test

329 dates. To perform this estimation we used symptom onset dates and positive test dates from 86

330 health care workers and 393 patients from Cambridge University Hospitals, fitting an offset

331 gamma distribution to these data (S5 Figure, S1 Table). Where symptom dates were missing,

332 the mean of this distribution was used to impute symptom onset dates from positive test dates.

333 We write $\hat{S}_{A}$ to denote an estimate for $S_{A}$. Where positive test dates are used in place of symptom

334 onset dates, greater care is required in the interpretation of results.

Location data

In our study, time was measured in whole days. For example, if an individual was known to be in of 0.5 .

Where location data were missing it was necessary to specify values $w_{A}(L, T)$. Data from our study were centred on cases from a specific part of the hospital, usually a single ward; this location was denoted $L^{*}$. Where location data were missing for a patient, we set $w_{A}\left(L^{*}, T\right)=1$ for all $T$,

348 assuming that a patient was always on the most common ward. Where location data were missing

349 for health care workers, we set $w_{A}\left(L^{*}, T\right)=4 / 7$ for all $T$, reflecting shift patterns. We note that in 350 other circumstances (e.g. a dataset spanning an entire hospital), an alternative prior for the 351 location of individuals could be more appropriate. 
medRxiv preprint doi: https://doi.org/10.1101/2020.10.26.20219642; this version posted April 21, 2021. The copyright holder for this preprint (which was not certified by peer review) is the author/funder, who has granted medRxiv a license to display the preprint in perpetuity.

It is made available under a CC-BY 4.0 International license .

353 Contact information was derived from the location data. For any two individuals we note that

354 there could be multiple locations in which they could be in contact on a single day. We combined

355 probabilities of contact across potential locations, calculating

$$
w_{A B}(t)=1-\prod_{L}\left(1-w_{A}(L, t) w_{B}(L, t)\right)
$$

Viral genome sequence data

Consensus genome sequences were calculated from viral sequence data. Sequences were $80 \%$ or more of the sites in the genome.

The second level of quality control counted ambiguous nucleotides that were found at sites in the genome that were found to be polymorphic between the collected viral sequences. These sites are more likely to be informative with regards to the number of genetic differences between two sequences; a genome with high overall coverage but ambiguity at multiple of these positions would in practice be quite uninformative. Having identified polymorphic sites, we required sequences to have no more than one ambiguous nucleotide at these positions.

374 In some cases, multiple viral samples were collected from the same individual. Viral genomes 375 collected from the same individual were usually extremely similar to one another (S1 Figure). In 376 such a case, we identified the earliest sequence with sufficient coverage of the viral genome, 377 using this sequence for analysis. Where positions in this genome were ambiguous, and where 
medRxiv preprint doi: https://doi.org/10.1101/2020.10.26.20219642; this version posted April 21, 2021. The copyright holder for this preprint (which was not certified by peer review) is the author/funder, who has granted medRxiv a license to display the preprint in perpetuity.

It is made available under a CC-BY 4.0 International license.

other sequences from the same individual had unambiguous nucleotides at these positions, the other sequences were used to construct a more complete consensus sequence for the individual.

Given viral sequences from the pair of individuals A and B we calculated Hamming distances from each sequence to a pairwise consensus sequence; we denote these distances as $H_{A}$ and $H_{B}$.

\section{Assessing viral transmission}

We denote as $\mathrm{X}_{\mathrm{T}}$ an indicator for the event that transmission took place at time $\mathrm{T}$, and as $\mathrm{X}$ an indicator for the event that transmission took place at all. To test the hypothesis of transmission, we calculated the probability of observing the data y under the null hypothesis that transmission occurred, $p(y \mid X)=\Sigma_{T} p\left(y \mid X_{T}\right) P\left(X_{T} \mid X\right)$, where $P\left(X_{T} \mid X\right)$ is the probability that transmission took place at $\mathrm{T}$ given transmission, which we abbreviate as $\mathrm{P}(\mathrm{T})$. probability of the observable data as follows:

where $D=\left\{D_{A}, D_{B}\right\}, E$ is the error in sequencing, and $\theta$ represents the set of parameters that are assumed to be known. We note that we condition on $S_{A}$; an alternative approach would be to write the equation in terms of $S_{B}-S_{A}$. We consider the parts of this equation in turn. 
medRxiv preprint doi: https://doi.org/10.1101/2020.10.26.20219642; this version posted April 21, 2021. The copyright holder for this preprint (which was not certified by peer review) is the author/funder, who has granted medRxiv a license to display the preprint in perpetuity.

It is made available under a CC-BY 4.0 International license .

404 In equation (1), $\mathrm{P}\left(\mathrm{T} \mid \mathrm{S}_{\mathrm{A}}, \theta\right)$ describes the probability that transmission is at time $\mathrm{T}$, where time is

405 measured relative to $S_{A}$, the time of onset of symptoms in $A$. This term describes the infectivity

406 profile of the virus, that is, the time from symptom onset to transmission. We follow previously

407 published work which has characterised this as an offset gamma distribution[16,17,35].

408

409 The term $P\left(S_{B} \mid \theta, X_{T}\right)$ describes the probability that $B$ becomes symptomatic at time $S_{B}$, given that

410 transmission occurs at time T. Again we have information from the same literature characterising

411 this as a lognormal distribution. We therefore write:

412

413

$P\left(T \mid S_{A}, \alpha, \beta, s\right)=\frac{e^{-\left(T-S_{A}+s\right) / \beta}\left(T-S_{A}+s\right)^{\alpha-1} \beta^{-\alpha}}{\Gamma(\alpha)},(2)$

414

415 where $s$ is the offset and $\alpha=97.1875, \beta=0.2689$, and $s=25.625$, and

$417 \quad P\left(S_{B} \mid \mu, \sigma, X_{T}\right)=\frac{e^{-\frac{\left(\log \left(S_{B}-T\right)-\mu\right)^{2}}{2 \sigma^{2}}}}{\left(S_{B}-T\right) \sigma \sqrt{2 \pi}}$,

where $\mu=1.434$, and $\sigma=0.6612$. Each of these expressions treat $T$ as a continuous variable ; we use an approximation to discretise the formula to a resolution of single days, obtaining

$P\left(T \mid S_{A}, \theta\right) P\left(S_{B} \mid \theta, X_{T}\right)=\left[\int_{T-S_{A}-0.5}^{T-S_{A}+0.5} \frac{e^{-(x+s) / \beta}(x+s)^{\alpha-1} \beta^{-\alpha}}{\Gamma(\alpha)} d x\right]\left[\int_{S_{B}-T-0.5}^{S_{B}-T+0.5} \frac{e^{-\frac{(\log (x)-\mu)^{2}}{2 \sigma^{2}}}}{x \sigma \sqrt{2 \pi}} d x\right]$

424 We next consider the term $\mathrm{P}\left(\mathrm{C}_{\mathrm{AB}} \mid \mathrm{X}_{\mathrm{T}}\right)$. Where $|\mathrm{C}|$ is the length of the vector $\mathrm{C}_{\mathrm{AB}}$, we note that there 425 are $2^{|C|}$ possible such vectors. If $C_{A B}(T)=0$, transmission cannot have occurred at time $T$, so that, 426 if transmission occurred at time, then $C_{A B}(T)$, the Tth element of $C_{A B}$, equals 1 . Regarding other 
medRxiv preprint doi: https://doi.org/10.1101/2020.10.26.20219642; this version posted April 21, 2021. The copyright holder for this preprint (which was not certified by peer review) is the author/funder, who has granted medRxiv a license to display the preprint in perpetuity.

It is made available under a CC-BY 4.0 International license .

427 elements of $C_{A B}$, we take a naive approach to contact patterns, assuming that $P\left(C_{A B}(t)=1 \mid X_{T}\right)=0.5$

428 for each $t$ not equal to $T$. This implies the result that $P\left(C_{A B} \mid X_{T}\right)=0.5^{|C|-1}$ for any $C_{A B}$ with $C_{A B}(T)=1$, 429 with $\mathrm{P}\left(\mathrm{C}_{\mathrm{AB}} \mid \mathrm{X}_{\mathrm{T}}\right)=0$ otherwise.

Assessing viral transmission: Viral sequence data

433 Finally, we consider the term $\mathrm{P}\left(\mathrm{H}_{\mathrm{A}}, \mathrm{H}_{\mathrm{B}} \mid \theta, \mathrm{D}, \mathrm{X}_{\mathrm{T}}\right)$, which is derived from the viral genome sequence

434 data. In order to generate $\mathrm{H}_{\mathrm{A}}$ and $\mathrm{H}_{\mathrm{B}}$, we first calculated a local consensus sequence across all

435 of the viral genomes in our data. Next, for each pair of sequences from individuals $A$ and $B$, we calculated a pairwise consensus, defined as the nucleotide shared by the two sequences where

437 the sequences agreed, and the nucleotide in the local consensus where the sequences differed.

$438 \mathrm{H}_{\mathrm{A}}$ and $\mathrm{H}_{\mathrm{B}}$ were then calculated as the Hamming distances from each of the two sequences to 439 the pairwise consensus sequence. These distances describe the number of substitutions 440 observed to have been gained by the viral population in each individual.

In our analysis we assumed an infinite sites model; among our sequences any given mutation can be obtained only once, while the reversion of mutations back to the consensus never occurs.

We used a Poisson model to compare the number of observed substitutions in each sequence with an expected rate of viral evolution. Our model includes a term accounting for errors in the

447 viral consensus sequences. In the notation of Figure 4, we note that if $D_{A}$ is before $T$, any variants 448 observed in sequence data from A but not in the data from B can only arise from error. Under our 449 infinite sites assumption, such variants cannot revert in the time between $D_{A}$ and $D_{B}$ so must be 450 caused by error in the observation. However, if $D_{A}$ is after $T$, such variants have the potential to 451 evolve in the time between $D_{A}$ and $T$, in addition to being potentially caused by measurement 452 error. 
medRxiv preprint doi: https://doi.org/10.1101/2020.10.26.20219642; this version posted April 21, 2021. The copyright holder for this preprint (which was not certified by peer review) is the author/funder, who has granted medRxiv a license to display the preprint in perpetuity.

It is made available under a CC-BY 4.0 International license.

454 Similarly, variants observed in data from B but not from A can arise either from error, or as a result

455 of evolution going back an assumed common ancestor at the earlier of the time of transmission

$456 T$ and the previous time of sequencing $D_{A}$. We can thus describe the probability of observing the

457 data $\mathrm{H}_{\mathrm{A}}$ and $\mathrm{H}_{\mathrm{B}}$ under the assumption of transmission at time $\mathrm{T}$ :

$$
\begin{aligned}
& P\left(H_{A}, H_{B} \mid \theta, D, E, X_{T}\right) \\
& \qquad=\left(\frac{\left(E / 2+\gamma_{G} P_{A}\right)^{H_{A}} e^{-\left(E / 2+\gamma_{G} P_{A}\right)}}{H_{A} !}\right)\left(\frac{\left(E / 2+\gamma_{G}\left(D_{B}-Q_{A}\right)\right)^{H_{B}} e^{-\left(E / 2+\gamma_{G}\left(D_{B}-Q_{A}\right)\right)}}{H_{B} !}\right)
\end{aligned}
$$

where $P_{A}=\max \left\{0, D_{A}-T\right\}$ and $Q_{A}=\min \left\{D_{A}, T\right\}$. The rate of evolution $\gamma_{G}$ describes the expected number of substitutions per genome per day, while the parameter $E$ is the mean number of errors in the Hamming distance between two viral sequences, estimated as described below.

In order to estimate the extent of measurement error in a consensus viral genome, we examined cases among data collected at Cambridge University Hospitals (CUH) for which more than one viral sample was sequenced. We identified 136 such patients, with between 2 and 9 samples

471 collected from each individual and 336 samples in total. Each sample gave rise to a consensus 472 sequence; we filtered the data to remove sequences with less than $90 \%$ coverage of the genome. 473 For each pair of samples $\mathrm{i}$ and $\mathrm{j}$, collected from the same individual, we recorded $\mathrm{H}_{\mathrm{ij}}$, the Hamming 474 distance between them, $\Delta \mathrm{T}_{\mathrm{ij}}$, the absolute difference in time between the dates on which the 475 samples were collected, measured in days, and the viral load of each sample, as represented by 476 the CT scores $\mathrm{V}_{\mathrm{i}}$ and $\mathrm{V}_{\mathrm{j}}$. 
medRxiv preprint doi: https://doi.org/10.1101/2020.10.26.20219642; this version posted April 21, 2021. The copyright holder for this preprint (which was not certified by peer review) is the author/funder, who has granted medRxiv a license to display the preprint in perpetuity.

It is made available under a CC-BY 4.0 International license .

478 Following in principle a previous approach to estimating noise and rates of evolution [32], we then

479 fitted a Poisson model to the data, deriving for each pair the log likelihood

480

481

$$
\log L^{D}\left(\varepsilon, \lambda, \gamma \mid H_{i j}, \Delta T_{i j}, V_{i}, V_{j}\right)=\log \left(\frac{\left(\frac{\varepsilon}{2}\left(V_{i}+V_{j}\right)+\lambda+\gamma \Delta T_{i j}\right)^{H_{i j}} e^{-\left(\frac{\varepsilon}{2}\left(V_{i}+V_{j}\right)+\lambda+\gamma \Delta T_{i j}\right)}}{H_{i j} !}\right)
$$

483 and estimating the parameters $\varepsilon, \lambda$ and $\gamma$ so as to maximise the sum of the log likelihoods across 484 all pairs of sequences; we inferred the parameters $\hat{\epsilon}=0.0200, \hat{\lambda}=-0.0693$ and $\hat{\gamma}=0.0453$. Here the 485 value $\hat{E}\left(V_{i}, V_{j}\right)=\hat{\lambda}+\hat{\epsilon}\left(V_{i}+V_{j}\right)$ provides a simple estimate of the extent of measurement error in 486 a Hamming distance, expressed in terms of the CT scores of the two samples. For the purposes 487 of our model this function was evaluated at the mean CT score of 24.091. This provided an 488 estimate for the pairwise difference arising through measurement error, $\hat{E}$, of 0.414 nucleotides, equivalent to 0.207 nucleotide errors per genome sequence. The estimate $\hat{\gamma}$ describes the mean rate of within-host evolution calculated across the within-host sample. It is expressed as a number 491 of substitutions per genome per day, and is equivalent to a rate of $6.0 \times 10^{-4}$ substitutions per 492 locus per year, close to the value of $8 \times 10^{-4}$ that has been calculated from global sequence data 493 [33]. In so far as we require an estimated rate of evolution spanning both within-host and 494 between-host evolution, we used in our model a rate $\widehat{\gamma_{G}}$ of 0.0655 nucleotides per day, equivalent 495 to this latter, globally estimated, rate of evolution.

497 To examine the effect of CT score upon our inference, a repeat calculation was performed in 498 which these data were ignored; this gave a worse fit to the data under the Bayesian Information 499 Criterion[34] (S2 Table). 
medRxiv preprint doi: https://doi.org/10.1101/2020.10.26.20219642; this version posted April 21, 2021. The copyright holder for this preprint (which was not certified by peer review) is the author/funder, who has granted medRxiv a license to display the preprint in perpetuity.

It is made available under a CC-BY 4.0 International license.

501 In a case where no sequence data was observed for an individual, we excluded that individual

502 from our calculation. An option within our method allows for calculations to be performed between

503 individuals where no sequence data was collected; under this option we set $P\left(H_{A}, H_{B} \mid \theta, D, E\right.$,

$\left.504 \mathrm{X}_{\mathrm{T}}\right)=1$ for all $\mathrm{A}$ and $\mathrm{B}$.

505

506 Assessing viral transmission: Hypothesis testing

507

508 Having derived the expression (1) for $P(Y \mid D, X)$, we now derive the probability $P(y \mid D, X)$ of the 509 specific observed data $y$. The data y consist of the symptom time $S_{B}$, if it is known, the Hamming

510 distances $\mathrm{H}_{A}$ and $\mathrm{H}_{B}$, the set of those $\mathrm{C}_{A B}(T)$ that are known, and the information about potential

511 locations and contacts in cases where the $C_{A B}(T)$ are unknown, which are encapsulated in $w_{A B}(T)$.

$512 p(y \mid D, X)$ is defined by setting $Y$ to equal the data $y$ that are observed, and then integrating

$513 \mathrm{P}(\mathrm{Y} \mid \mathrm{D}, \mathrm{X})$ over the potential values for any missing data.

514

515 Integration was required with respect to the unknown contact dates, applying to the term

$516 P\left(C_{A B} \mid X_{T}\right)$. We generalise the argument made for this term in the case of $Y$ to show that in this

517 case we have

518

519

$P\left(C_{A B} \mid X_{T}\right)=0.5^{|C|-1} W_{A B}(T)$

520

521 A full derivation is given in S1 Text.

522

523 We thus have the result

524

525

$p(y \mid D, X)=\sum_{T} P\left(T \mid \widehat{S_{A}}, \theta\right) P\left(\widehat{S_{B}} \mid \theta, X_{T}\right) 0.5^{|C|-1} w_{A B}(T) P\left(H_{A}, H_{B} \mid \theta, D, X_{T}\right)$, 
medRxiv preprint doi: https://doi.org/10.1101/2020.10.26.20219642; this version posted April 21, 2021. The copyright holder for this preprint (which was not certified by peer review) is the author/funder, who has granted medRxiv a license to display the preprint in perpetuity.

527 where $\theta=\left\{\alpha, \beta, s, \mu, \sigma, \hat{E}, Y_{G}\right\}$, and seek to compare this to potential values $p(Y \mid D, X)$. To achieve this, 528 for confidence level $\psi$, we define a threshold $\mathrm{p}_{\psi}(\mathrm{D})$ by

$$
\int_{Y \in \Omega_{\psi}} p(Y \mid D, X)=\psi
$$

where $\Omega_{\psi}=\left\{Y: p(Y \mid D, X) \geq p_{\psi}(D)\right\}$. Note that the threshold $p_{\psi}(D)$ depends on the sample collection times $D=\left\{D_{A}, D_{B}\right\}$. For values $\psi=0.95$ and $\psi=0.99$, the observed data $y$ is deemed 'consistent' with transmission if $p(y \mid D, X) \geq p_{95}(D)$, 'borderline' if $p_{95}(D)>p(y \mid D, X) \geq p_{99}(D)$, and unlikely if $p_{99}(D)>$ $\mathrm{p}(\mathrm{y} \mid \mathrm{D}, \mathrm{X})$.

To identify these threshold values we calculated $p(Y \mid D, X)$ across large numbers of sets of data $Y$, in which we assumed without loss of generality that $S_{A}=0$. Calculations were performed for all

$539 Y$ in which $S_{B} \in[-11,87]$, and for all values $H_{A}$ and $H_{B}$ for which $H_{A}+H_{B} \in[0,10]$ and $H_{A} \in[0$,

$540 \mathrm{H}_{\mathrm{A}}+\mathrm{H}_{B}$ ]; these ranges were chosen to return values of at least $10^{-6}$ from each component of $541 p(Y \mid D, X)$. In our code these statistics are calculated for $D_{A} \in[-10,40]$, and $D_{B} \in\left[S_{B}-10, S_{B}+40\right]$;

542 values outside of these parameters are unlikely.

544 In the integral, we note that there are a large number of possible vectors $C_{A B}$ that indicate all times

545 when a pair were in contact. We approximated the sum by generating 100 random vectors $C_{A B}$

546 for each set of other parameters, and calculating the sum over these vectors, altering the value

$5470.5^{|\mathrm{Cl}|-1}$ in $\mathrm{P}\left(\mathrm{C}_{\mathrm{AB}} \mid \mathrm{X}_{\mathrm{T}}\right)$ so as to normalise the integral. Reflecting our approach to contact patterns, 548 we generated the $C_{A B}$ as random vectors of draws from a Bernoulli distribution with mean 0.5. 549 Repeating this calculation with different sets of 100 vectors did not substantially change the 550 thresholds obtained. Our code allows for the generation of alternative thresholds with different 
medRxiv preprint doi: https://doi.org/10.1101/2020.10.26.20219642; this version posted April 21, 2021. The copyright holder for this preprint (which was not certified by peer review) is the author/funder, who has granted medRxiv a license to display the preprint in perpetuity.

It is made available under a CC-BY 4.0 International license .

551 probabilities of an element of $C_{A B}$ being equal to 1 . We note that if this probability is higher, fewer

552 datasets will be judged consistent with transmission.

Study setting, participants and data collection

This study was conducted at Cambridge University Hospitals NHS Foundation Trust (CUH), a secondary and tertiary referral centre in the East of England. SARS-CoV-2 positive cases tested at the on-site Public Health England (PHE) Clinical Microbiology and Public Health Laboratory (CMPHL) were identified prospectively from 26th February to 17th June 2020. The CMPHL tests SARS-CoV-2 samples submitted from over thirty organisations across the East of England (EoE) region and all samples from $\mathrm{CUH}$. The majority of samples were tested using an in-house validated qRT-PCR assay targeting the SARS-CoV-2 RdRp genes, as described in a previous publication [5], with more recent samples tested using the Hologic Panther ${ }^{\mathrm{TM}}$ platform [36]. Patient metadata were accessed via the electronic healthcare record system (Epic Systems, Verona, WI, USA). Metadata collected included patient demographic information, duration of symptoms, sample collection date and location (ward and hospital). Patients and samples were assigned unique anonymised study codes. Metadata manipulations were performed using the $\mathrm{R}$ programming language and the tidyverse packages installed on CUH Trust computers.

Sample sequencing

572 All samples collected at $\mathrm{CUH}$ and a randomised selection of samples from the EoE region were 573 selected for nanopore sequencing on-site in the Division of Virology, Department of Pathology, 574 University of Cambridge. This enabled us to rapidly investigate suspected hospital acquired 575 infections at CUH as previously described [5]. Briefly, a multiplex PCR based approach was used 576 according to the modified ARTIC version 2 protocol with version 3 primer set, and amplicon 
medRxiv preprint doi: https://doi.org/10.1101/2020.10.26.20219642; this version posted April 21, 2021. The copyright holder for this preprint (which was not certified by peer review) is the author/funder, who has granted medRxiv a license to display the preprint in perpetuity.

It is made available under a CC-BY 4.0 International license .

577 libraries sequenced using MinION flow cells version 9.4.1 (Oxford Nanopore Technologies,

578 Oxford, UK). Sequences were made publicly available as part of COG-UK

579 (https://www.cogconsortium.uk/) via weekly uploads with linked metadata onto the MRC-CLIMB

580 server (https://www.climb.ac.uk/).

582 Samples collected via the CUH healthcare worker (HCW) screening programme were also

583 prioritised for on-site nanopore sequencing, as previously described [37]. This programme

584 entailed asymptomatic screening of selected wards, symptomatic testing of self-presenting HCW

585 and testing of symptomatic contacts of positive HCW. After a HCW tested positive, members of

586 the HCW screening team contacted the HCW and retrospectively collected data on symptom

587 onset date, symptomatology, household contacts, their job role, and which wards they had worked

588 in for the preceding two weeks. Most positive HCW could identify symptoms on retrospective

589 questioning, even if they were identified in the asymptomatic screening arm; however, a small

590 minority were genuinely asymptomatic and never went on to develop symptoms. HCW presenting

591 acutely to medical services at CUH were not part of the HCW screening programme, but were

592 identified as HCW from their medical records as part of hospital surveillance.

Identifying hospital-associated outbreaks for investigation

596 Patients tested at CUH were categorised on the basis of time between admission and first positive

597 swab into different groups reflecting the likelihood that their infection was community or hospital

598 acquired, as previously described (Meredith et al, LID 2020). The categories used were: 1)

599 Community onset, community associated (first positive sample $<48$ hours from admission and no

600 healthcare contact in the preceding 14 days); 2) Community onset, suspected healthcare

601 associated (first positive sample $<48$ hours from admission with healthcare contact in the

602 preceding 14 days); 3) Hospital onset, indeterminate healthcare associated (first positive sample 
medRxiv preprint doi: https://doi.org/10.1101/2020.10.26.20219642; this version posted April 21, 2021. The copyright holder for this preprint (which was not certified by peer review) is the author/funder, who has granted medRxiv a license to display the preprint in perpetuity.

It is made available under a CC-BY 4.0 International license.

60348 hours to 7 days post admission); 4) Hospital onset, suspected healthcare associated (first

604 positive sample 8 to 14 days post admission); 5) Hospital onset, healthcare associated (first

605 positive sample $>14$ days post admission); 6) HCW.

606

607 All CUH patients in categories 3, 4, and 5 (hospital onset with indeterminate, suspected or definite

608 healthcare associated COVID-19 infections) and 6 (HCW) were included for analysis and

609 integrated into the HCW screening dataset of positive HCW. The main wards the HCW had

610 worked in prior to testing positive and the ward where each patient had first tested positive were

611 used to identify ward clusters of hospital-associated infections. The ward clusters are named

612 anonymously here as Wards $\mathrm{X}$ and $\mathrm{Y}$.

613

614 Ethics statement

615

616 This study was conducted as part of surveillance for COVID-19 infections under the auspices of

617 Section 251 of the NHS Act 2006. It therefore did not require individual patient consent or ethical

618 approval. The COG-UK study protocol was approved by the Public Health England Research

619 Ethics Governance Group (reference: R\&D NR0195).

620

621

622 Figures

623 


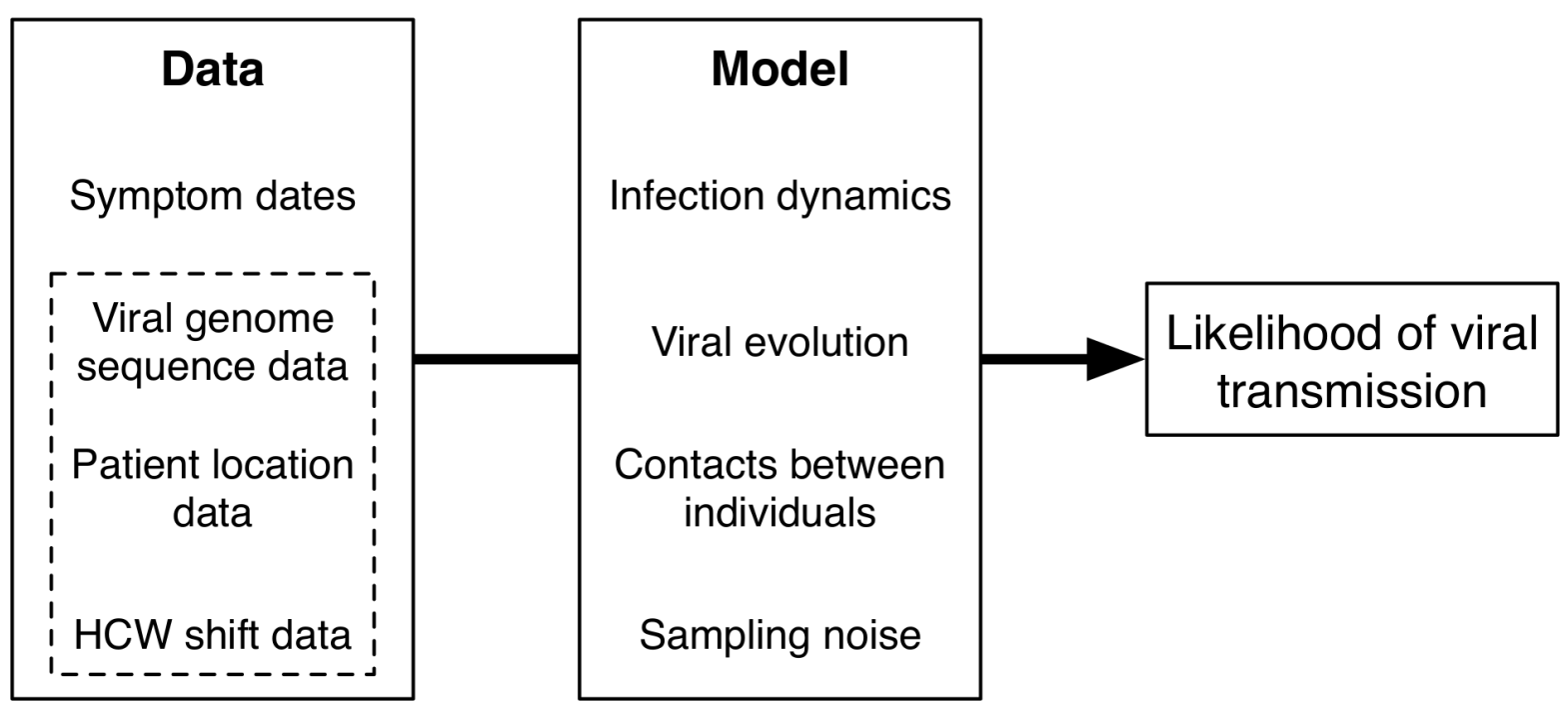

626 Figure 1: Overview of our method. Our approach estimates the likelihood that transmission

627 could have occurred between pairs of individuals. The model takes as input dates on which

628 individuals became symptomatic for COVID-19 infection. Further data which can be considered

629 includes viral genome sequence data, and time-resolved location data for each individual. Our

630 model combines details of COVID-19 infection dynamics with a model of viral evolution,

631 information about potential contacts between individuals, and measurement error in the sequence

632 data. Increasing amounts of data provide increasing amounts of resolution about the potential for 633 viral transmission. 
medRxiv preprint doi: https://doi.org/10.1101/2020.10.26.20219642; this version posted April 21, 2021. The copyright holder for this preprint (which was not certified by peer review) is the author/funder, who has granted medRxiv a license to display the preprint in perpetuity.

It is made available under a CC-BY 4.0 International license .

A

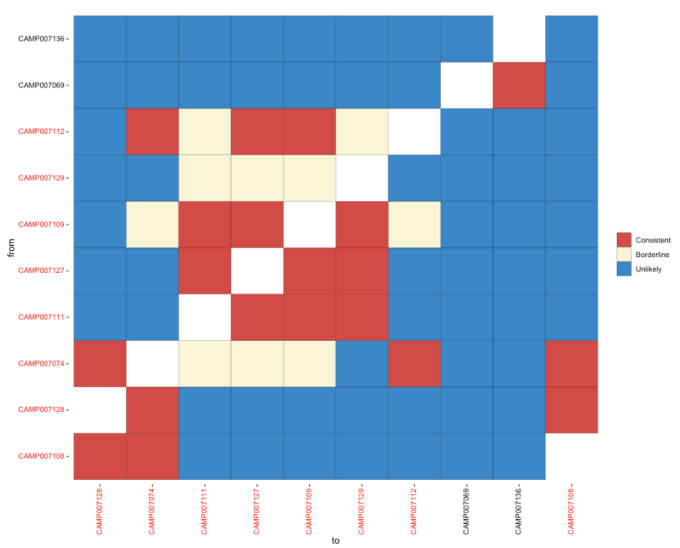

C

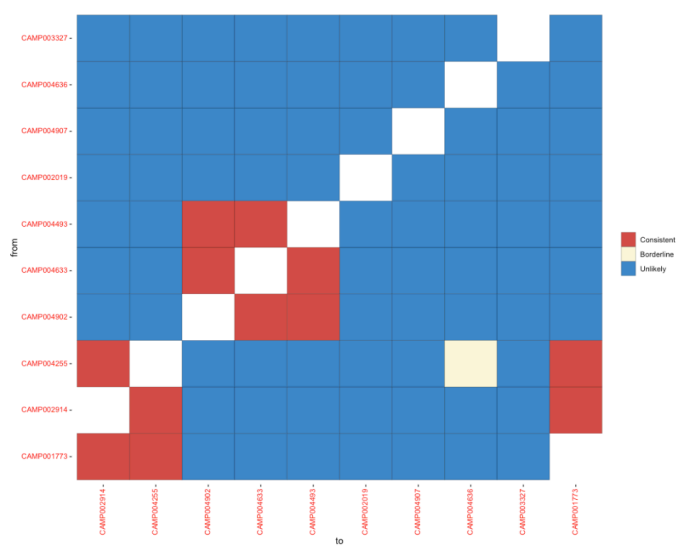

B

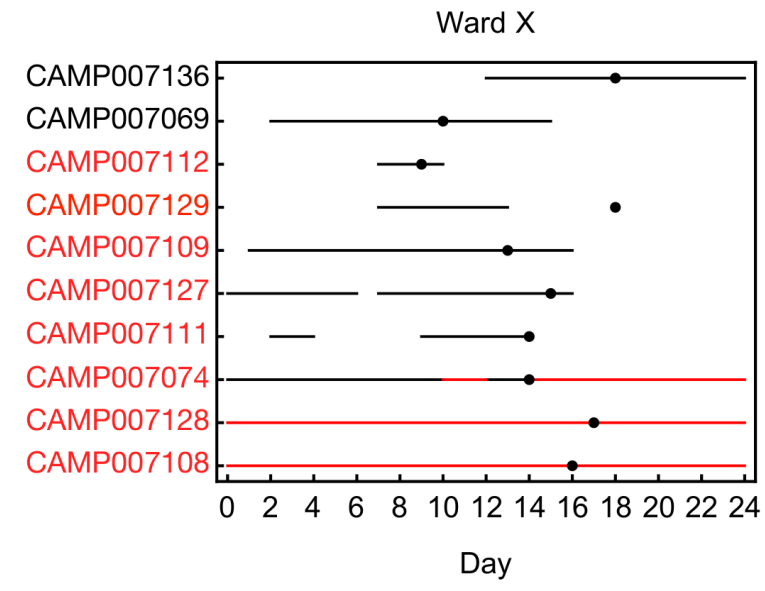

D

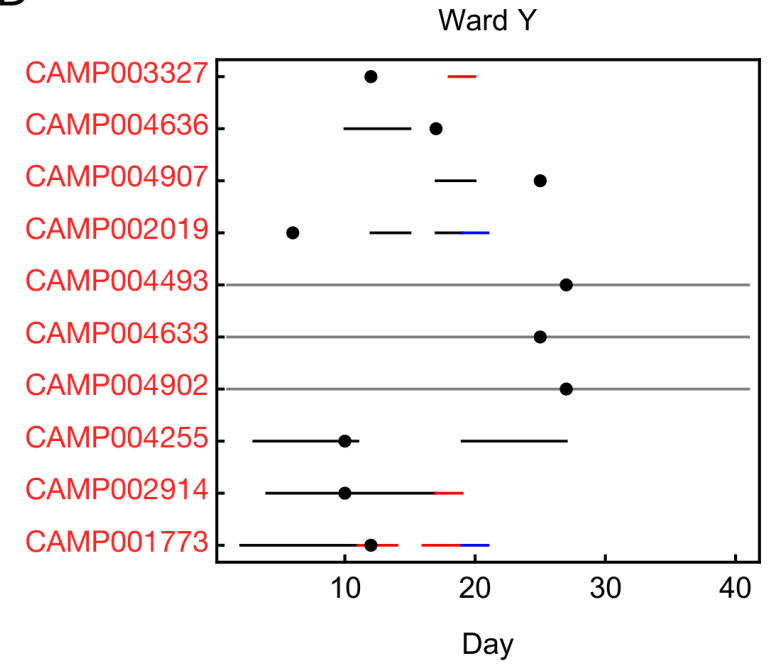

635 Figure 2: Analysis of the full datasets collected from wards $\mathbf{X}$ and $\mathrm{Y}$. A. Output from the

636 a2bcovid package given data from ward X. The plot shows potential links between cases, 637 assessed in a pairwise fashion between potential donors (rows) and recipients (columns).

638 Identifiers of individuals are coloured in either black (patients) or red (HCWs). Squares in the grid 639 indicate that transmission from one individual to another is consistent with our model (red),

640 borderline (yellow) or unlikely (blue). B. Locations of individuals linked to the ward X outbreak.

641 Black lines indicate presence on ward X. Red lines indicate known household contacts between

642 three individuals. Dots show times at which individuals first reported symptoms. C. Output from

643 the a2bcovid package given data from ward $Y$. D. Locations of individuals linked to the ward $Y$ 
medRxiv preprint doi: https://doi.org/10.1101/2020.10.26.20219642; this version posted April 21, 2021. The copyright holder for this preprint (which was not certified by peer review) is the author/funder, who has granted medRxiv a license to display the preprint in perpetuity.

It is made available under a CC-BY 4.0 International license .

644 outbreak. Black lines indicate presence on ward Y. Red and blue lines show presence in

645 locations other than ward $\mathrm{Y}$.

A

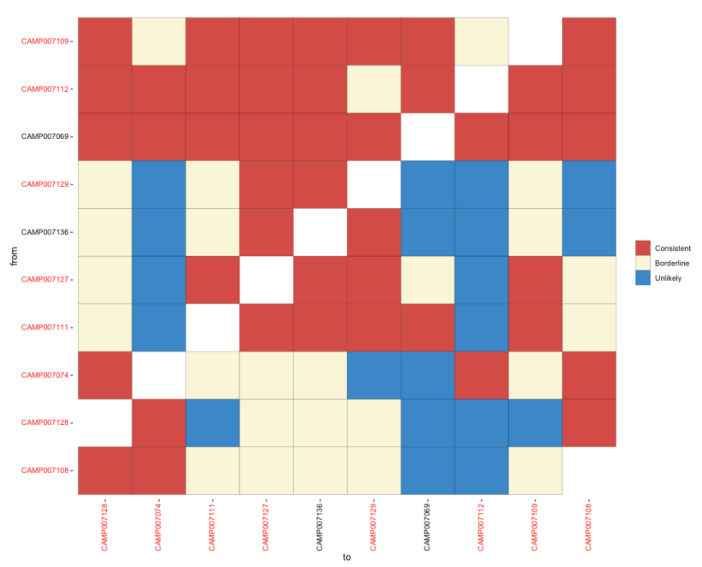

C

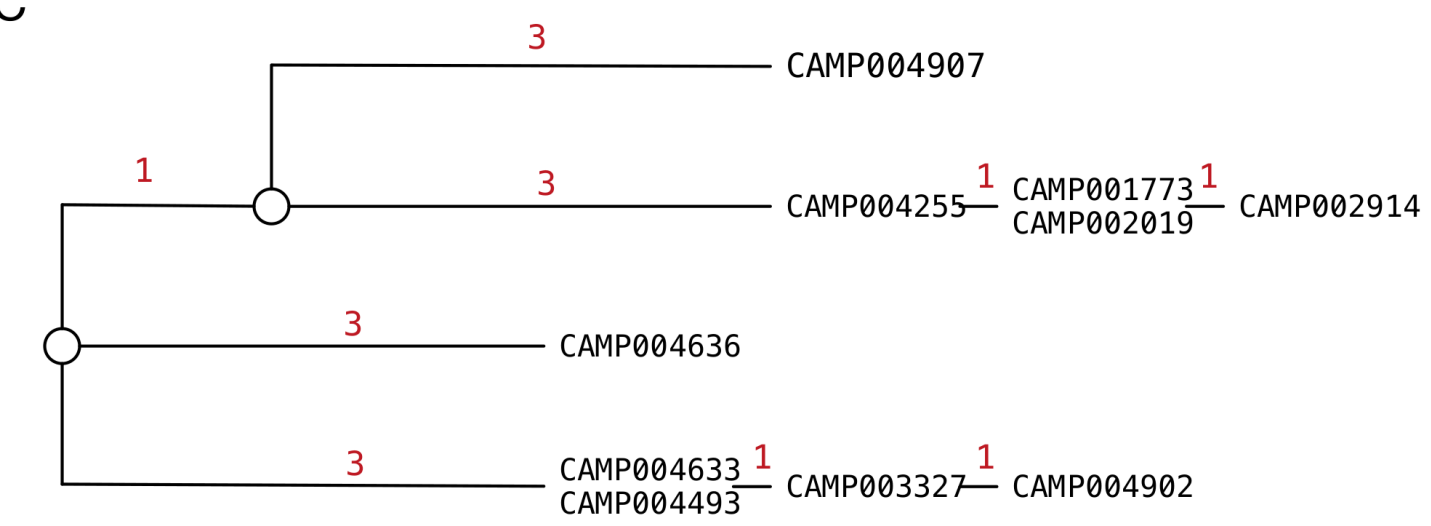

647

648 Figure 3: Analysis of the symptom onset and sequence data collected from wards $X$ and

649 Y. A. Output from the a2bcovid package given data from ward X, omitting location data for 650 individuals. The plot shows potential links between infections. Identifiers of individuals are 651 coloured in either black (patients) or red (HCWs). Squares in the grid indicate that transmission 652 from one individual to another is consistent with our model (red), borderline (yellow) or unlikely 653 (blue). B. Output from the a2bcovid package given data from ward $\mathrm{Y}$, omitting location data for 654 individuals. C. Phylogenetic relationship between sequences collected from individuals on ward 
medRxiv preprint doi: https://doi.org/10.1101/2020.10.26.20219642; this version posted April 21, 2021. The copyright holder for this preprint (which was not certified by peer review) is the author/funder, who has granted medRxiv a license to display the preprint in perpetuity.

It is made available under a CC-BY 4.0 International license.

656 indicate the number of substitutions between sequences from each individual.

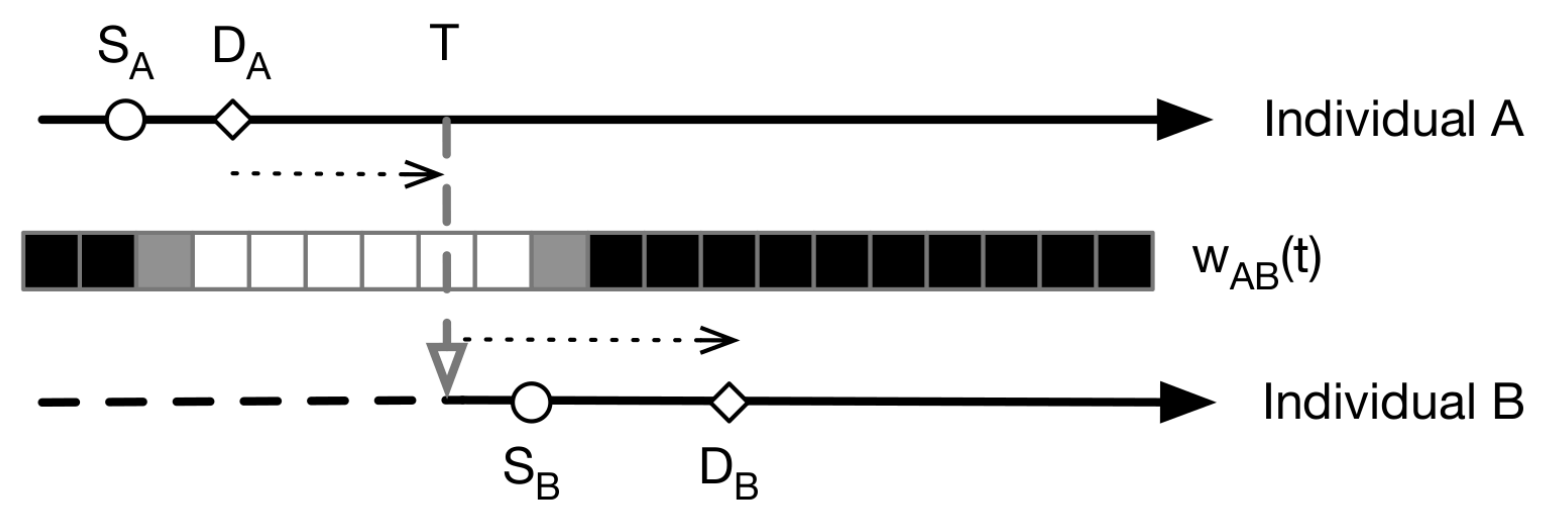

\section{$\mathrm{S}_{\mathrm{i}}$ : Time of individual i becoming symptomatic \\ $D_{i}$ : Time of collecting sequence from individual $i$ \\ $\mathrm{T}$ : Time of transmission from $\mathrm{i}$ to $\mathrm{j}$ \\ $\mathrm{w}_{\mathrm{ij}}$ : Location weighting for individuals $\mathrm{i}$ and $\mathrm{j}$}

Figure 4: Notation used in our method. An overview of our model for transmission events is shown in Figure 3. We divide time into discrete days. For the individual $A$, we denote by $S_{A}$ the date at which that individual became symptomatic, and by $D_{A}$ the date at which a sample of viruses were collected for genome sequencing. For each pair of individuals $A$ and $B$ we denote by $w_{A B}(t)$ two individuals. 


\section{A}
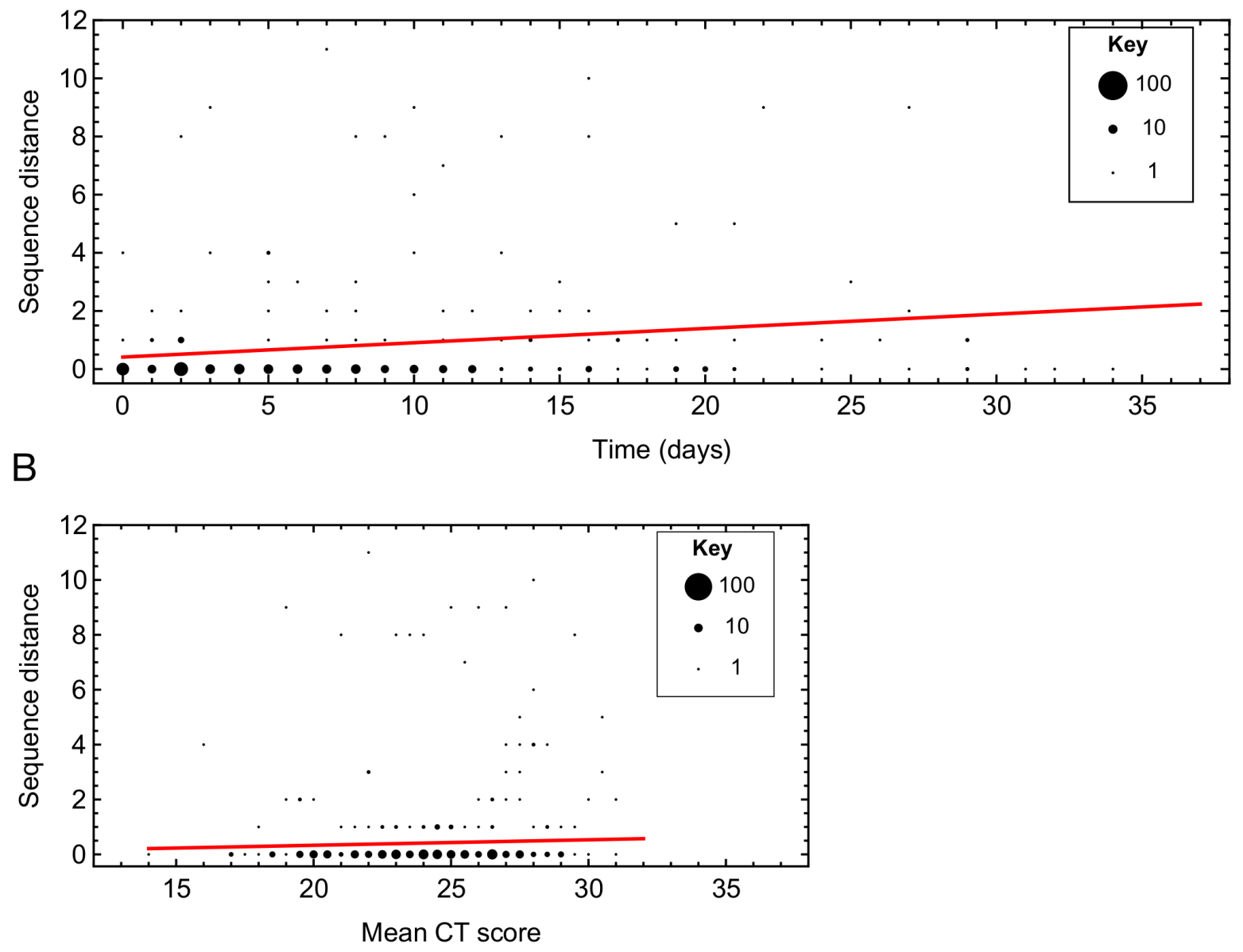

672

673 S1 Figure: Analysis of Hamming distances between pairs of genome sequences collected from

674 viral samples in the same host. Figures show projections through a multi-linear model fit to the

675 data using a Poisson likelihood. A. Relationship between the Hamming distance and time

676 between samples. The line shows the fit to the data at the mean CT score. The size of a dot is

677 proportional to the number of pairs with given parameters. B. Relationship between the Hamming

678 distance and mean CT score of the two samples. The line shows the fit to the data calculated at

679 zero time between samples. 
medRxiv preprint doi: https://doi.org/10.1101/2020.10.26.20219642; this version posted April 21, 2021. The copyright holder for this preprint (which was not certified by peer review) is the author/funder, who has granted medRxiv a license to display the preprint in perpetuity.

It is made available under a CC-BY 4.0 International license .

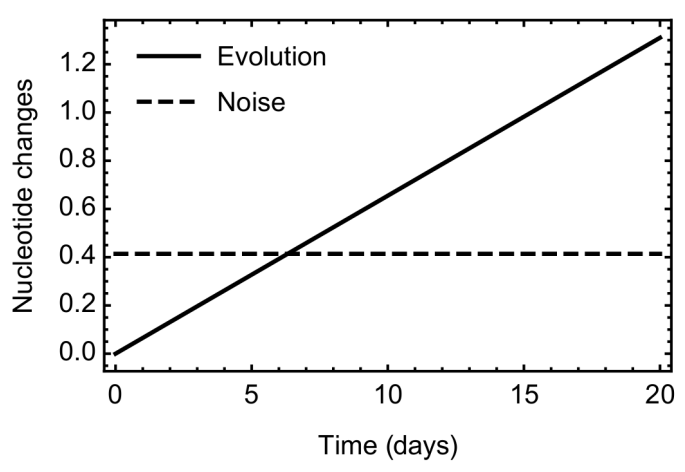

682

683 S2 Figure: Comparison between the expected rate of SARS-CoV-2 evolution within our model,

684 and the expected difference between two sequences caused by noise. The expected time

685 between symptoms being reported from individuals in a transmission pair is 5.7 days, in which

686 time the expected number of substitutions arising via evolution is 0.373 . The expected number

687 of differences between two genome sequences resulting from error was estimated as 0.414 .

688

A

689

690

691

692

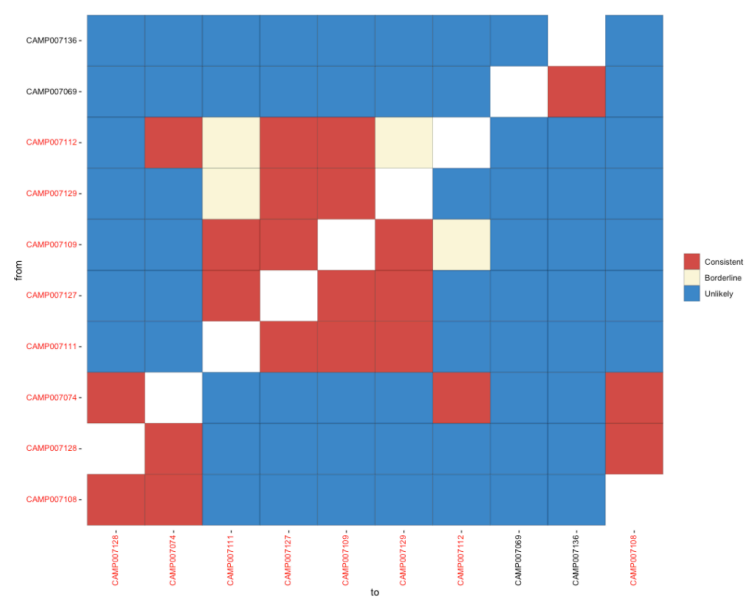

$\mathrm{B}$

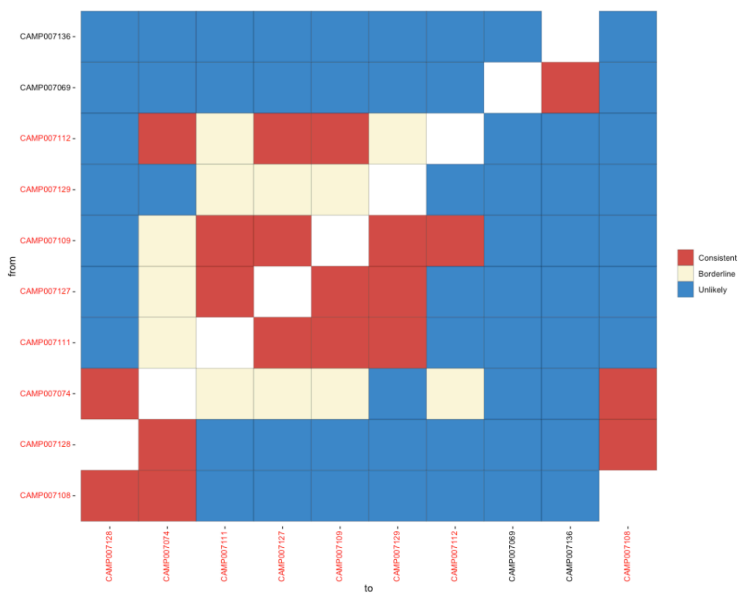

S3 Figure: Sensitivity of our results to changes in the noise parameter. A. Inferences of potential transmission events for ward $\mathrm{X}$ given a noise parameter of zero. B. Inferences of 
medRxiv preprint doi: https://doi.org/10.1101/2020.10.26.20219642; this version posted April 21, 2021. The copyright holder for this preprint (which was not certified by peer review) is the author/funder, who has granted medRxiv a license to display the preprint in perpetuity.

It is made available under a CC-BY 4.0 International license .

693 potential transmission events for ward $X$ given a noise parameter double that inferred from our

694 data.

695

696

697

698

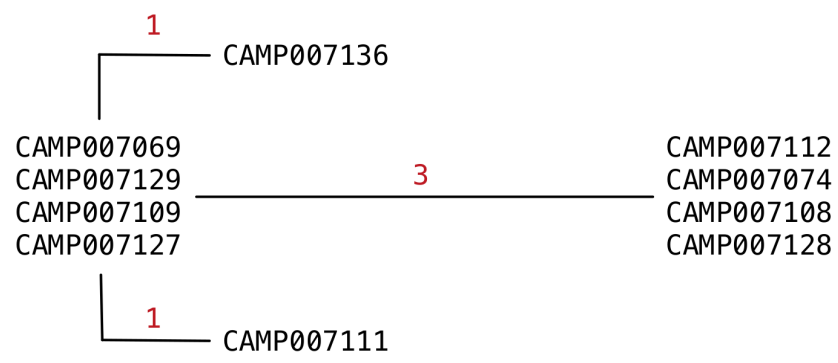

699

700 S4 Figure: Phylogenetic relationship between sequences collected from individuals on ward X.

701 The tree was constructed manually using a maximum parsimony method. Red digits indicate the

702 number of substitutions between sequences from each individual

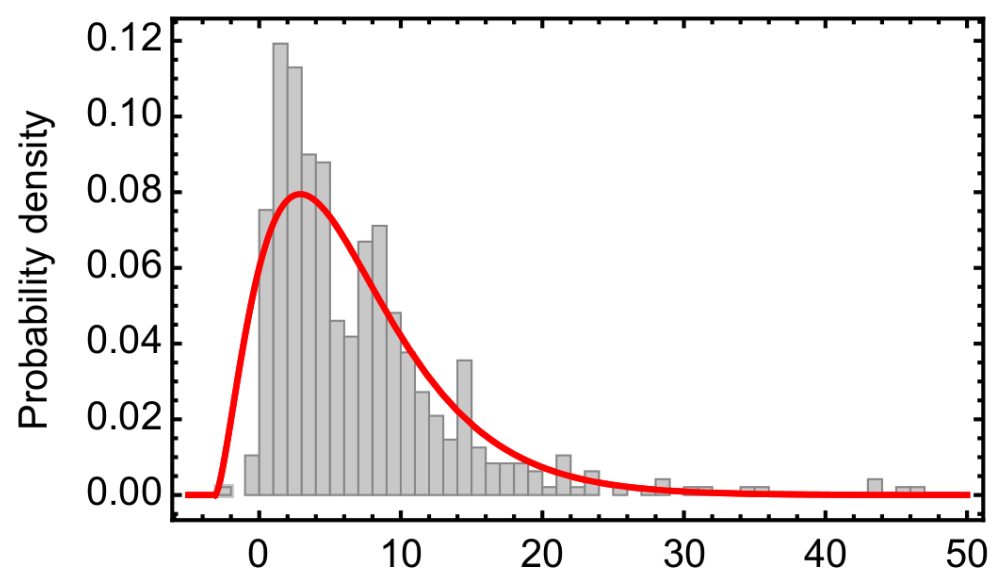

Days from symptom onset to positive test

704 S5 Figure: Raw data (bars) and inferred model (red line) describing the distribution of the time 705 between the onset of symptoms and receiving a positive test. This model was used to impute? 
medRxiv preprint doi: https://doi.org/10.1101/2020.10.26.20219642; this version posted April 21, 2021. The copyright holder for this preprint (which was not certified by peer review) is the author/funder, who has granted medRxiv a license to display the preprint in perpetuity.

It is made available under a CC-BY 4.0 International license .

equivalent symptom onset dates for individuals who were asymptomatic or for whom no data on

707 symptom onset date were available.

708

709 S1 Table: Parameters for the offset gamma distribution fitted to data describing intervals between

710 times of reporting symptoms and positive test results. Inferred values were generated using

711 maximum likelihood; the range describes a window of size two likelihood units from the maximum.

\begin{tabular}{|l|l|}
\hline Model & \\
\hline Parameter & Value (Range) \\
\hline $\boldsymbol{\alpha}$ & $2.593(2.269,2.976)$ \\
\hline $\boldsymbol{\beta}$ & $3.776(3.292,4.353)$ \\
\hline Offset (o) & $3.112(3.011,3.431)$ \\
\hline
\end{tabular}

713

714 S2 Table: Error models fitted to Hamming distance data. A model incorporating dependence 715 upon the time between samples and upon viral load gave the best fit to the data. The error 716 parameter used was calculated at zero time between samples and the mean viral load.

\begin{tabular}{|l|l|l|l|l|}
\hline Model & \multicolumn{3}{|c|}{ Parameters } & BIC \\
\hline & Constant $(\lambda)$ & $\begin{array}{l}\text { Time dependence } \\
(\mathrm{V})\end{array}$ & CT dependence $(\boldsymbol{\alpha})$ & \\
& & & & \\
\hline Constant error & 0.842 & & & 887.3 \\
\hline
\end{tabular}




\begin{tabular}{|l|l|l|l|l|}
\hline Time-dependent & 0.385 & 0.0525 & & 858.5 \\
\hline Time and CT & -0.0692 & 0.0492 & 0.0200 & 857.8 \\
dependent & & & & \\
\hline
\end{tabular}

In the main text we stated that:

$P\left(C_{A B} \mid X_{T}\right)=0.5^{|C|-1} W_{A B}(T)$

726 To derive this result we note that, if it is observed that $C_{A B}(T)=0$, transmission cannot occur at

727 time $T$, so that $P\left(C_{A B} \mid X_{T}\right)=0$. If it is observed that $C_{A B}(T)=1$, we next consider the element $C_{A B}(t)$

728 of $C_{A B}$ for a time $t \neq T$. If $C_{A B}(t)$ is observed, we apply our approach to contact patterns, assuming

729 that $P\left(C_{A B}(t)=1 \mid X_{T}\right)=P\left(C_{A B}(t)=0 \mid X_{T}\right)=0.5$, such that the probability of this observation is 0.5 . If $730 \mathrm{C}_{A B}(\mathrm{t})$ is not observed, its probability is obtained by integration. We have that $\mathrm{P}\left(\mathrm{C}_{\mathrm{AB}}(\mathrm{t}) \mid \mathrm{X}_{T}\right)=$

$731 \mathrm{w}_{\mathrm{AB}}(\mathrm{t})^{*} 0.5+\left(1-\mathrm{w}_{\mathrm{AB}}(\mathrm{t})\right){ }^{*} 0.5=0.5$. Hence if $\mathrm{C}_{\mathrm{AB}}(\mathrm{T})=1$, the probability $\mathrm{P}\left(\mathrm{C}_{\mathrm{AB}} \mid \mathrm{X}_{\mathrm{T}}\right)$ of the whole

732 contact vector is equal to $0.5^{|\mathrm{Cl}|-1}$. Finally, we consider the case in which $\mathrm{C}_{\mathrm{AB}}(\mathrm{T})$ is missing data.

733 Integrating over the missing value, we have that

734

735 $P\left(C_{A B}(T) \mid X_{T}\right)=w_{A B}(T)^{*} P\left(C_{A B} \mid X_{T}, C_{A B}(T)=1\right)+\left(1-w_{A B}(T)\right)^{*} P\left(C_{A B} \mid X_{T}, C_{A B}(T)=0\right)=w_{A B}(T)$ 
medRxiv preprint doi: https://doi.org/10.1101/2020.10.26.20219642; this version posted April 21, 2021. The copyright holder for this preprint (which was not certified by peer review) is the author/funder, who has granted medRxiv a license to display the preprint in perpetuity.

It is made available under a CC-BY 4.0 International license.

737 Applying again the reasoning above, this gives us the result $P\left(C_{A B} \mid X_{T}\right)=0.5^{|C|-1} W_{A B}(T)$. As we

738 defined $w_{A B}(T)=C_{A B}(T)$ when $C_{A B}(T)$ was observed, we thus have that $P\left(C_{A B} \mid X_{T}\right)=0.5^{|C|-1} w_{A B}(T)$

739 in every case.

740

741 S2 Text: GISAID identifiers for sequences used in this study

742

743 Ward X: EPI_ISL_473479, EPI_ISL_473505, EPI_ISL_473478, EPI_ISL_473470,

744 EPI_ISL_473475, EPI_ISL_473464, EPI_ISL_473467, EPI_ISL_473466, EPI_ISL_473465,

745 EPI_ISL_473472, EPI_ISL_473471

746

747 Ward Y: EPI_ISL_425263, EPI_ISL_433686, EPI_ISL_444320, EPI_ISL_433740,

748 EPI_ISL_444407, EPI_ISL_433479, EPI_ISL_433779, EPI_ISL_433481, EPI_ISL_448052,

749 EPI_ISL_433492, EPI_ISL_433990

750

751 Measurement error analysis: EPI_ISL_444341, EPI_ISL_434058, EPI_ISL_438599,

752 EPI_ISL_425289, EPI_ISL_433900, EPI_ISL_425316, EPI_ISL_425424, EPI_ISL_433822,

753 EPI_ISL_433820, EPI_ISL_425314, EPI_ISL_447952, EPI_ISL_433796, EPI_ISL_433814,

754 EPI_ISL_433816, EPI_ISL_433666, EPI_ISL_425333, EPI_ISL_438723, EPI_ISL_433473,

755 EPI_ISL_434042, EPI_ISL_425334, EPI_ISL_433978, EPI_ISL_438648, EPI_ISL_434020,

756 EPI_ISL_444418, EPI_ISL_434059, EPI_ISL_438627, EPI_ISL_433671, EPI_ISL_433893,

757 EPI_ISL_433827, EPI_ISL_434004, EPI_ISL_433775, EPI_ISL_434060, EPI_ISL_433938,

758 EPI_ISL_444420, EPI_ISL_438714, EPI_ISL_448108, EPI_ISL_433895, EPI_ISL_438631,

759 EPI_ISL_438594, EPI_ISL_433911, EPI_ISL_444425, EPI_ISL_425309, EPI_ISL_433899,

760 EPI_ISL_433967, EPI_ISL_433681, EPI_ISL_425235, EPI_ISL_425259, EPI_ISL_425423,

761 EPI_ISL_425252, EPI_ISL_425251, EPI_ISL_438650, EPI_ISL_425274, EPI_ISL_425427,

762 EPI_ISL_425271, EPI_ISL_425270, EPI_ISL_425268, EPI_ISL_433673, EPI_ISL_433698, 
medRxiv preprint doi: https://doi.org/10.1101/2020.10.26.20219642; this version posted April 21, 2021. The copyright holder for this preprint (which was not certified by peer review) is the author/funder, who has granted medRxiv a license to display the preprint in perpetuity. It is made available under a CC-BY 4.0 International license .

763 EPI_ISL_433675, EPI_ISL_433697, EPI_ISL_425453, EPI_ISL_433679, EPI_ISL_433677,

764 EPI_ISL_433748, EPI_ISL_433784, EPI_ISL_438669, EPI_ISL_433672, EPI_ISL_434057,

765 EPI_ISL_433737, EPI_ISL_438580, EPI_ISL_438673, EPI_ISL_433477, EPI_ISL_433727,

766 EPI_ISL_433750, EPI_ISL_433752, EPI_ISL_433706, EPI_ISL_433707, EPI_ISL_433846,

767 EPI_ISL_433721, EPI_ISL_438706, EPI_ISL_433732, EPI_ISL_444416, EPI_ISL_433806,

768 EPI_ISL_434039, EPI_ISL_433966, EPI_ISL_433761, EPI_ISL_433768, EPI_ISL_433792,

769 EPI_ISL_433873, EPI_ISL_433881, EPI_ISL_433868, EPI_ISL_444329, EPI_ISL_444408,

770 EPI_ISL_433867, EPI_ISL_433878, EPI_ISL_433863, EPI_ISL_433467, EPI_ISL_433864,

771 EPI_ISL_433888, EPI_ISL_444403, EPI_ISL_434023, EPI_ISL_433892, EPI_ISL_433907,

772 EPI_ISL_433904, EPI_ISL_433906, EPI_ISL_438583, EPI_ISL_438647, EPI_ISL_444427,

773 EPI_ISL_433909, EPI_ISL_433920, EPI_ISL_438721, EPI_ISL_444413, EPI_ISL_433921,

774 EPI_ISL_433919, EPI_ISL_433980, EPI_ISL_433937, EPI_ISL_433993, EPI_ISL_433940,

775 EPI_ISL_434031, EPI_ISL_438586, EPI_ISL_433466, EPI_ISL_444419, EPI_ISL_433944,

776 EPI_ISL_433943, EPI_ISL_438651, EPI_ISL_433945, EPI_ISL_433969, EPI_ISL_438595,

777 EPI_ISL_434006, EPI_ISL_433972, EPI_ISL_434030, EPI_ISL_433986, EPI_ISL_434061,

778 EPI_ISL_433992, EPI_ISL_438668, EPI_ISL_438702, EPI_ISL_438649, EPI_ISL_444428,

779 EPI_ISL_434034, EPI_ISL_438578, EPI_ISL_438660, EPI_ISL_434036, EPI_ISL_438643,

780 EPI_ISL_444417, EPI_ISL_434015, EPI_ISL_433493, EPI_ISL_444316, EPI_ISL_434044,

781 EPI_ISL_438662, EPI_ISL_438622, EPI_ISL_438596, EPI_ISL_434045, EPI_ISL_444374,

782 EPI_ISL_434041, EPI_ISL_448052, EPI_ISL_433481, EPI_ISL_438632, EPI_ISL_433471,

783 EPI_ISL_444412, EPI_ISL_433468, EPI_ISL_444369, EPI_ISL_433478, EPI_ISL_433475,

784 EPI_ISL_438652, EPI_ISL_433476, EPI_ISL_438719, EPI_ISL_444326, EPI_ISL_447957,

785 EPI_ISL_444402, EPI_ISL_433474, EPI_ISL_444406, EPI_ISL_438670, EPI_ISL_444404,

786 EPI_ISL_444376, EPI_ISL_452887, EPI_ISL_438582, EPI_ISL_444429, EPI_ISL_444411,

787 EPI_ISL_447980, EPI_ISL_444422, EPI_ISL_444373, EPI_ISL_438672, EPI_ISL_444421,

788 EPI_ISL_477785, EPI_ISL_456720, EPI_ISL_448012, EPI_ISL_453003, EPI_ISL_456719, 
medRxiv preprint doi: https://doi.org/10.1101/2020.10.26.20219642; this version posted April 21, 2021. The copyright holder for this preprint (which was not certified by peer review) is the author/funder, who has granted medRxiv a license to display the preprint in perpetuity.

It is made available under a CC-BY 4.0 International license .

789 EPI_ISL_438568, EPI_ISL_444324, EPI_ISL_444414, EPI_ISL_448110, EPI_ISL_438623,

790 EPI_ISL_438588, EPI_ISL_438592, EPI_ISL_444339, EPI_ISL_438609, EPI_ISL_438646,

791 EPI_ISL_438584, EPI_ISL_438728, EPI_ISL_438637, EPI_ISL_438591, EPI_ISL_438679,

792 EPI_ISL_438671, EPI_ISL_438593, EPI_ISL_438658, EPI_ISL_438656, EPI_ISL_447948,

793 EPI_ISL_438653, EPI_ISL_438645, EPI_ISL_438644, EPI_ISL_447974, EPI_ISL_438678,

794 EPI_ISL_438674, EPI_ISL_438676, EPI_ISL_438699, EPI_ISL_448016, EPI_ISL_438680,

795 EPI_ISL_447961, EPI_ISL_438701, EPI_ISL_438681, EPI_ISL_444371, EPI_ISL_447978,

796 EPI_ISL_448014, EPI_ISL_444323, EPI_ISL_438697, EPI_ISL_448087, EPI_ISL_438737,

797 EPI_ISL_452946, EPI_ISL_452962, EPI_ISL_444343, EPI_ISL_444361, EPI_ISL_456743,

798 EPI_ISL_447977, EPI_ISL_452997, EPI_ISL_447955, EPI_ISL_447990, EPI_ISL_452922,

799 EPI_ISL_453002, EPI_ISL_447994, EPI_ISL_456703, EPI_ISL_452973, EPI_ISL_452912,

800 EPI_ISL_448017, EPI_ISL_448036, EPI_ISL_456686, EPI_ISL_448092, EPI_ISL_473460,

801 EPI_ISL_448043, EPI_ISL_452911, EPI_ISL_452936, EPI_ISL_448050, EPI_ISL_456717,

802 EPI_ISL_448106, EPI_ISL_473469, EPI_ISL_456724, EPI_ISL_448105, EPI_ISL_452935,

803 EPI_ISL_456737, EPI_ISL_452868, EPI_ISL_448099, EPI_ISL_456741, EPI_ISL_452863,

804 EPI_ISL_452963, EPI_ISL_461562, EPI_ISL_452939, EPI_ISL_452938, EPI_ISL_452951,

805 EPI_ISL_456704, EPI_ISL_452994, EPI_ISL_456709, EPI_ISL_452989, EPI_ISL_452985,

806 EPI_ISL_461558, EPI_ISL_452984, EPI_ISL_461573, EPI_ISL_473451, EPI_ISL_456708,

807 EPI_ISL_456725, EPI_ISL_456728, EPI_ISL_456701, EPI_ISL_461585, EPI_ISL_456699,

808 EPI_ISL_461561, EPI_ISL_456749, EPI_ISL_473484, EPI_ISL_473485, EPI_ISL_456742,

809 EPI_ISL_461546, EPI_ISL_461587, EPI_ISL_461571, EPI_ISL_461554, EPI_ISL_473463,

810 EPI_ISL_461565, EPI_ISL_461568, EPI_ISL_473501, EPI_ISL_473473

811

812

813 Author contributions

814 
medRxiv preprint do: https://doi.org/10.1101/2020.10.26.20219642; this version posted April 21, 2021. The copyright holder for this preprint (which was not certified by peer review) is the author/funder, who has granted medRxiv a license to display the preprint in perpetuity. It is made available under a CC-BY 4.0 International license.

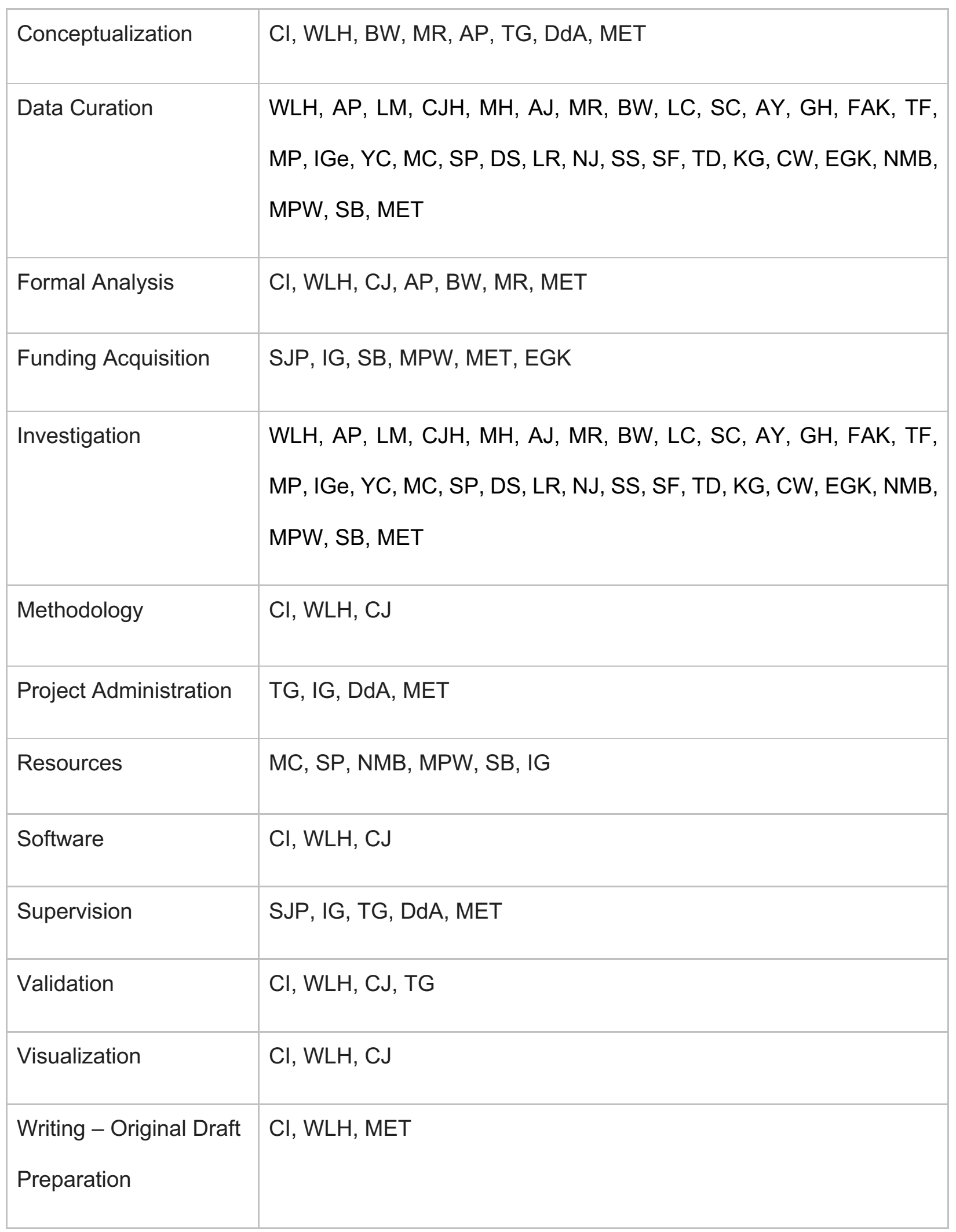


medRxiv preprint doi: https://doi.org/10.1101/2020.10.26.20219642; this version posted April 21, 2021. The copyright holder for this preprint (which was not certified by peer review) is the author/funder, who has granted medRxiv a license to display the preprint in perpetuity.

It is made available under a CC-BY 4.0 International license .

\begin{tabular}{l|l} 
Writing - Review \& $\quad$ All authors
\end{tabular}

Editing

817 Acknowledgements

819 This work was funded by COG-UK, which is supported by funding from the Medical Research

820 Council (MRC) part of UK Research \& Innovation (UKRI), the National Institute of Health

821 Research (NIHR) and Genome Research Limited, operating as the Wellcome Sanger Institute;

822 We also acknowledge the support from the Wellcome (Senior Clinical Fellowship to MPW (ref:

$823108070 / Z / 15 / Z)$, Senior Research Fellowship to SB (ref: 215515/Z/19/Z), Senior Fellowship to IG

824 (ref: 097997/Z/11/Z); Collaborative Grant to CJH (ref: 204870/Z/16/Z); the Academy of Medical

825 Sciences \& the Health Foundation (Clinician Scientist Fellowship to MET), the NIHR Cambridge

826 Biomedical Research Centre (to BW, MET) and the NIHR Clinical Research Network

827 Greenshoots award (to EGK). CJRI was supported by Deutsche Forschungsgemeinschaft (DFG)

828 Grant SFB 1310. We acknowledge MRC funding (ref: MC_UU_00002/11).

829

830 Availability of code

831

832 Our app is suitable for use with the $R$ package and can be downloaded from

833 http://github.com/chjackson/a2bcovid.

\section{References}

836 1. Andersen KG, Rambaut A, Lipkin WI, Holmes EC, Garry RF. The proximal origin of SARS837 CoV-2. Nat Med. 2020;26: 450-452.

838 2. Dong E, Du H, Gardner L. An interactive web-based dashboard to track COVID-19 in real 
medRxiv preprint doi: https://doi.org/10.1101/2020.10.26.20219642; this version posted April 21, 2021. The copyright holder for this preprint (which was not certified by peer review) is the author/funder, who has granted medRxiv a license to display the preprint in perpetuity.

time. Lancet Infect Dis. 2020;20: 533-534.

3. Danis K, Epaulard O, Bénet T, Gaymard A, Campoy S, Botelho-Nevers E, et al. Cluster of Coronavirus Disease 2019 (COVID-19) in the French Alps, February 2020. Clin Infect Dis. 2020;71: 825-832.

4. Gao Y, Shi C, Chen Y, Shi P, Liu J, Xiao Y, et al. A cluster of the Corona Virus Disease 2019 caused by incubation period transmission in Wuxi, China. J Infect. 2020;80: 666-670.

5. Meredith LW, Hamilton WL, Warne B, Houldcroft CJ, Hosmillo M, Jahun AS, et al. Rapid implementation of SARS-CoV-2 sequencing to investigate cases of health-care associated COVID-19: a prospective genomic surveillance study. Lancet Infect Dis. 2020. doi:10.1016/S1473-3099(20)30562-4

6. Kretzschmar ME, Rozhnova G, Bootsma MCJ, van Boven M, van de Wijgert JHHM, Bonten MJM. Impact of delays on effectiveness of contact tracing strategies for COVID-19: a modelling study. Lancet Public Health. 2020;5: e452-e459.

7. Rickman HM, Rampling T, Shaw K, Martinez-Garcia G, Hail L, Coen P, et al. Nosocomial Transmission of Coronavirus Disease 2019: A Retrospective Study of 66 Hospital-acquired Cases in a London Teaching Hospital. Clinical Infectious Diseases. 2020. doi:10.1093/cid/ciaa816

10. Biek R, Pybus OG, Lloyd-Smith JO, Didelot X. Measurably evolving pathogens in the

11. Brenner BG, Roger M, Stephens D, Moisi D, Hardy I, Weinberg J, et al. Transmission clustering drives the onward spread of the HIV epidemic among men who have sex with men in Quebec. J Infect Dis. 2011;204: 1115-1119.

12. Ragonnet-Cronin M, Hodcroft E, Hué S, Fearnhill E, Delpech V, Brown AJL, et al.

13. Jacka B, Applegate T, Krajden M, Olmstead A, Harrigan PR, Marshall B, et al. Phylogenetic Automated analysis of phylogenetic clusters. BMC Bioinformatics. 2013;14: 317. clustering of hepatitis $\mathrm{C}$ virus among people who inject drugs in Vancouver, Canada. Hepatology. 2014;60: 1571-1580.

14. Gire SK, Goba A, Andersen KG, Sealfon RSG, Park DJ, Kanneh L, et al. Genomic surveillance elucidates Ebola virus origin and transmission during the 2014 outbreak. Science. 2014;345: 1369-1372.

15. McCloskey RM, Poon AFY. A model-based clustering method to detect infectious disease transmission outbreaks from sequence variation. PLoS Comput Biol. 2017;13: e1005868.

16. Li Q, Guan X, Wu P, Wang X, Zhou L, Tong Y, et al. Early Transmission Dynamics in Wuhan, China, of Novel Coronavirus-Infected Pneumonia. N Engl J Med. 2020;382: 1199_ 
medRxiv preprint doi: https://doi.org/10.1101/2020.10.26.20219642; this version posted April 21, 2021. The copyright holder for this preprint (which was not certified by peer review) is the author/funder, who has granted medRxiv a license to display the preprint in perpetuity.

1207.

17. He X, Lau EHY, Wu P, Deng X, Wang J, Hao X, et al. Temporal dynamics in viral shedding

18. Du Z, Xu X, Wu Y, Wang L, Cowling BJ, Meyers LA. Serial Interval of COVID-19 among

19. Prete CA, Buss L, Dighe A, Porto VB, da Silva Candido D, Ghilardi F, et al. Serial Interval Distribution of SARS-CoV-2 Infection in Brazil. J Travel Med. 2020. doi:10.1093/jtm/taaa115

20. Lipsitch M, Donnelly CA, Fraser C, Blake IM, Cori A, Dorigatti I, et al. Potential Biases in Estimating Absolute and Relative Case-Fatality Risks during Outbreaks. PLoS Negl Trop Dis. 2015;9: e0003846.

21. Buitrago-Garcia D, Egli-Gany D, Counotte MJ, Hossmann S, Imeri H, Ipekci AM, et al. Occurrence and transmission potential of asymptomatic and presymptomatic SARS-CoV-2

23. Laehnemann D, Borkhardt A, McHardy AC. Denoising DNA deep sequencing data-highthroughput sequencing errors and their correction. Brief Bioinform. 2016;17: 154-179.

24. Sandmann $S$, de Graaf $A O$, Karimi $M$, van der Reijden BA, Hellström-Lindberg $E$, Jansen $\mathrm{JH}$, et al. Evaluating Variant Calling Tools for Non-Matched Next-Generation Sequencing Data. Sci Rep. 2017;7: 43169.

25. Illingworth CJR, Roy S, Beale MA, Tutill H, Williams R, Breuer J. On the effective depth of viral sequence data. Virus Evol. 2017;3: vex030.

26. Worby CJ, Lipsitch M, Hanage WP. Shared Genomic Variants: Identification of Transmission Routes Using Pathogen Deep-Sequence Data. Am J Epidemiol. 2017;186: 1209-1216.

\section{De Maio N, Worby CJ, Wilson DJ, Stoesser N. Bayesian reconstruction of transmission} within outbreaks using genomic variants. PLoS Comput Biol. 2018;14: e1006117.

28. McCrone JT, Woods RJ, Martin ET, Malosh RE, Monto AS, Lauring AS. Stochastic processes constrain the within and between host evolution of influenza virus. Elife. 2018;7. doi:10.7554/eLife.35962

29. Lumby CK, Nene NR, Illingworth CJR. A novel framework for inferring parameters of transmission from viral sequence data. PLoS Genet. 2018;14: e1007718.

30. Houldcroft CJ, Beale MA, Breuer J. Clinical and biological insights from viral genome sequencing. Nat Rev Microbiol. 2017;15: 183-192.

31. Maljkovic Berry I, Melendrez MC, Bishop-Lilly KA, Rutvisuttinunt W, Pollett S, Talundzic E, et al. Next Generation Sequencing and Bioinformatics Methodologies for Infectious Disease Research and Public Health: Approaches, Applications, and Considerations for 
medRxiv preprint doi: https://doi.org/10.1101/2020.10.26.20219642; this version posted April 21, 2021. The copyright holder for this preprint (which was not certified by peer review) is the author/funder, who has granted medRxiv a license to display the preprint in perpetuity.

It is made available under a CC-BY 4.0 International license.

Development of Laboratory Capacity. J Infect Dis. 2020;221: S292-S307.

917

918

919

920

921

922

923
32. Lumby CK, Zhao L, Breuer J, Illingworth CJ. A large effective population size for established within-host influenza virus infection. Elife. 2020;9. doi:10.7554/eLife.56915

33. Hadfield J, Megill C, Bell SM, Huddleston J, Potter B, Callender C, et al. Nextstrain: realtime tracking of pathogen evolution. Bioinformatics. 2018;34: 4121-4123.

34. Schwarz G. Estimating the Dimension of a Model. The Annals of Statistics. 1978. pp. 461464. doi:10.1214/aos/1176344136

35. Ashcroft P, Huisman JS, Lehtinen S, Bouman JA, Althaus CL, Regoes RR, et al. COVID-19 infectivity profile correction. Swiss medical weekly. 2020. p. w20336.

36. Sridhar S, Forrest S, Kean I, Young J, Scott JB, Maes M, et al. A blueprint for the implementation of a validated approach for the detection of SARS-Cov2 in clinical samples in academic facilities. doi:10.1101/2020.04.14.041319

37. Rivett L, Sridhar S, Sparkes D, Routledge M, Jones NK, Forrest S, et al. Screening of healthcare workers for SARS-CoV-2 highlights the role of asymptomatic carriage in COVID19 transmission. Elife. 2020;9. doi:10.7554/eLife.58728

38. Fitch WM. Toward Defining the Course of Evolution: Minimum Change for a Specific Tree Topology. Systematic Zoology. 1971. p. 406. doi:10.2307/2412116 